\title{
Resource-based destination competitiveness evaluation using analytic hierarchy process (AHP): The case study of West Virginia
}

Yanhong Zhou

Follow this and additional works at: https://researchrepository.wvu.edu/etd

\section{Recommended Citation}

Zhou, Yanhong, "Resource-based destination competitiveness evaluation using analytic hierarchy process (AHP): The case study of West Virginia" (2014). Graduate Theses, Dissertations, and Problem Reports. 7049.

https://researchrepository.wvu.edu/etd/7049

This Thesis is protected by copyright and/or related rights. It has been brought to you by the The Research Repository @ WVU with permission from the rights-holder(s). You are free to use this Thesis in any way that is permitted by the copyright and related rights legislation that applies to your use. For other uses you must obtain permission from the rights-holder(s) directly, unless additional rights are indicated by a Creative Commons license in the record and/ or on the work itself. This Thesis has been accepted for inclusion in WVU Graduate Theses, Dissertations, and Problem Reports collection by an authorized administrator of The Research Repository @ WVU. For more information, please contact researchrepository@mail.wvu.edu. 


\title{
RESOURCE-BASED DESTINATION COMPETITIVENESS EVALUATION USING ANALYTIC HIERARCHY PROCESS (AHP): THE CASE STUDY OF WEST VIRGINIA
}

\author{
Yanhong Zhou
}

Thesis submitted

to the Davis College of Agriculture, Natural Resources and Design at West Virginia University

in partial fulfillment of the requirements for the degree of

Master of Science in

Recreation, Parks, and Tourism Resources

Kudzayi Maumbe, Ph.D., Chair Jinyang Deng, Ph.D.

Steve Selin, Ph.D.

Division of Forestry and Natural Resources

Morgantown, West Virginia

2014

Keywords: tourist, tourism destination, resource-based view (RBV), destination competitiveness, analytic hierarchy process (AHP), West Virginia Copyright 2014 Yanhong Zhou 


\section{ABSTRACT \\ Resource-based Destination Competitiveness Evaluation Using Analytic Hierarchy Process (AHP): the Case Study of West Virginia}

\section{Yanhong Zhou}

This study aimed to evaluate West Virginia's resource-based tourism competitiveness in relation to its neighboring competitors using analytic hierarchy process (AHP). The study also sought to investigate the utility of AHP in destination competitiveness evaluation. Ten executive directors from West Virginia's Convention and Visitors Bureaus (CVBs) and 891 visitors to West Virginia participated in this study. Findings revealed that West Virginia performed well on availability of adventure-based activities, nature-based activities, and had a competitive edge on hospitality and friendliness of residents, safety and security, and value for money in shopping items in relation to competing destinations. AHP was shown to be a reliable tool to evaluate destination competitiveness. Theoretical and managerial implications and future research suggestions are discussed. 


\section{Acknowledgements}

I would not have been able to complete this study without the mentor, support, and encouragement from many significant persons. My sincere thanks go out to all the significant ones who have helped me during the design and writing of the thesis.

Kudzayi Maumbe, the chair of my thesis committee, helped me during my master study journey with her intelligence and warm heart. I owe my accomplishment of the master degree to her. I also thank Dr. Jingyang Deng for his tireless advice to me on both academic and life choices, and Dr. Steve Selin for his insightful ideas about my thesis design and writing.

Special thanks are also extended to Dr. Robert C. Burns for his mentor about research method and research attitude, Dr. Dave Smaldone for this encouragement and emotional support, and Sera Zegre for her timely great ideas about the writing of Chapter 2.

Thanks also go to the 10 West Virginia CVB executive directors for their input into the design of the study's research questions.

Most importantly, I thank Jesus Christ, the Almighty God, for blessing me and guiding me through the difficulties I encountered to complete this study. 


\section{Dedication}

This thesis is dedicated to my mother-in-law, Fen Zhang, my husband, Feng Jin, and my one-year-old daughter, Angela Z. Jin. 


\section{Table of Contents}

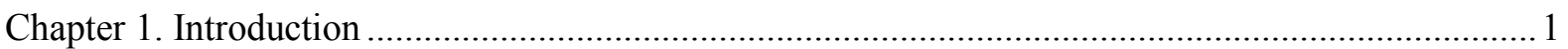

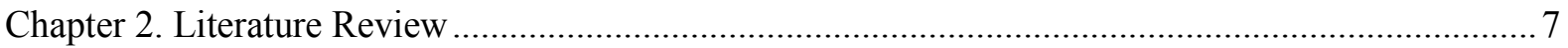

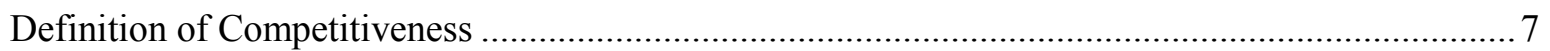

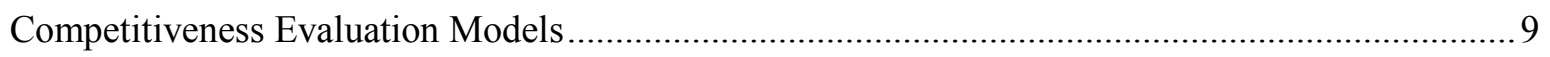

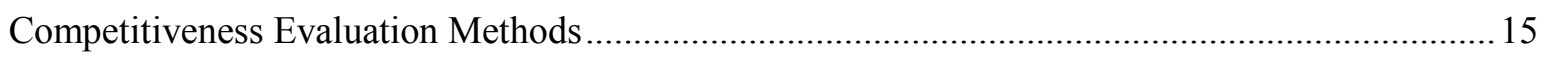

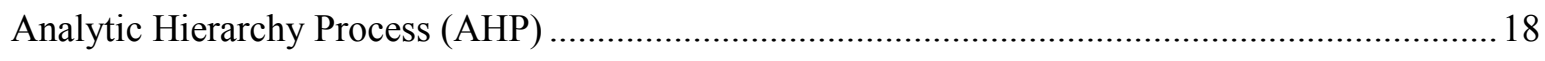

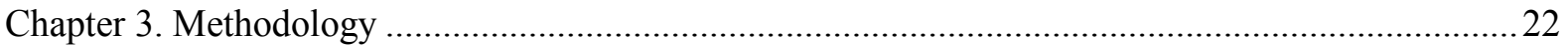

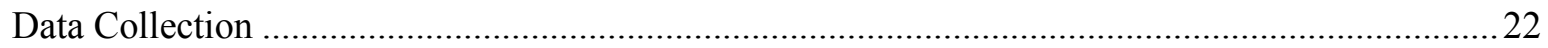

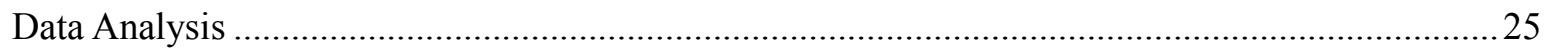

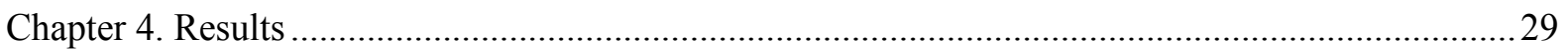

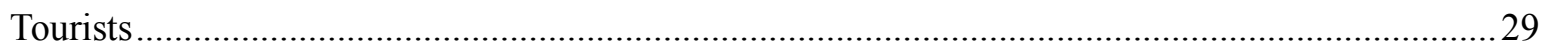

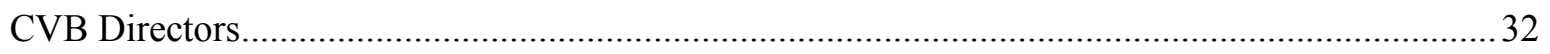

What is the proper model to evaluate West Virginia's tourism competitiveness? ............................ 34

What are the most and least important tourism attributes for West Virginia's tourism

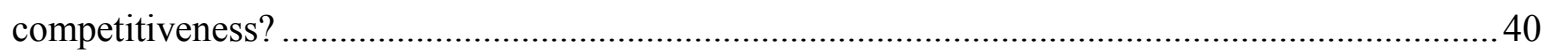

What are the strengths and weaknesses of West Virginia as a tourism destination compared to

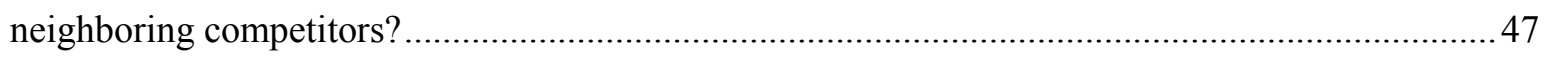

What is West Virginia's overall competitive position in relation to its neighboring competitors? ...51

Does the AHP method make a significant difference in destination competitiveness evaluation

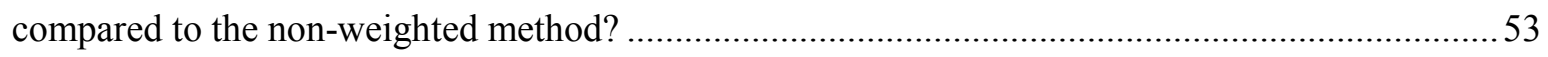

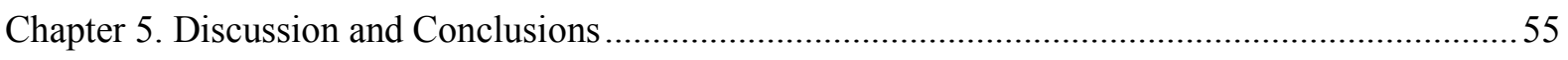

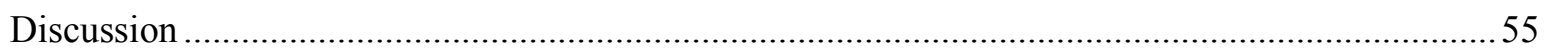

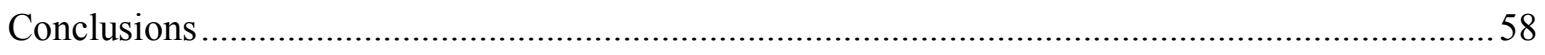

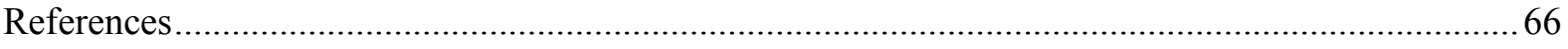

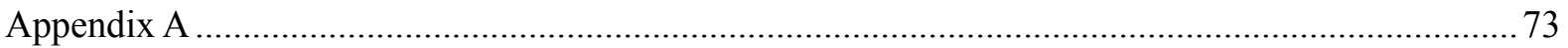

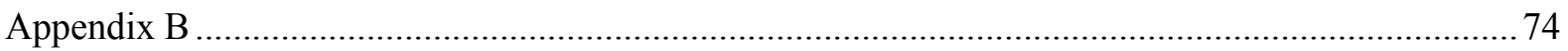

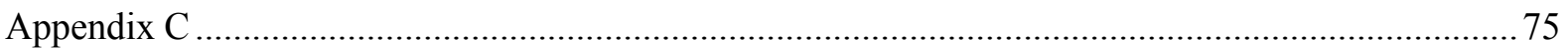

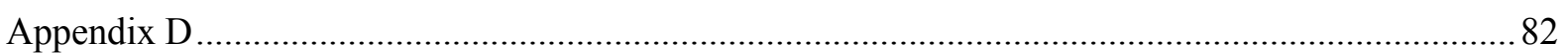

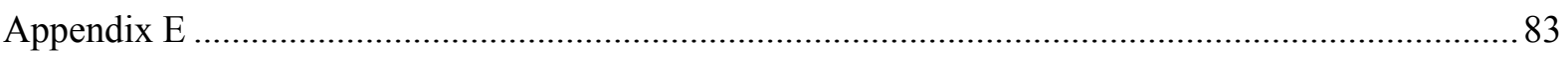




\section{List of Tables}

Table 1. Destination Competitiveness Attributes Used in the First Stage Data Collection...................23

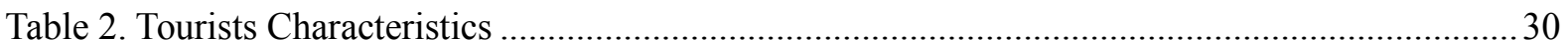

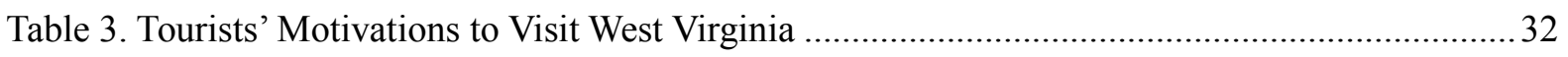

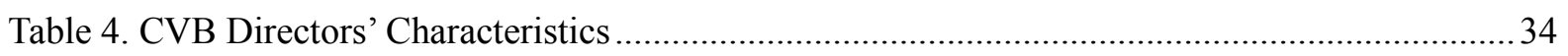

Table 5. Allocation of Competitiveness Attributes in Literature-based Model ..................................... 37

Table 6. Competitiveness Determinants and Corresponding Indicators Based on Factor Analysis...... 39

Table 7. Tourism Attributes Weights and West Virginia's Performance on the Attributes .................... 47

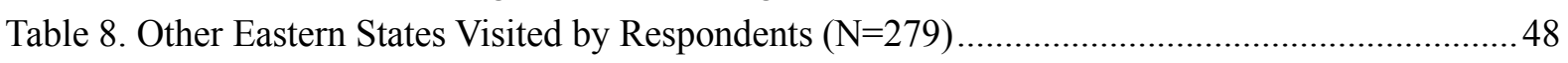

Table 9. Four Destinations' Weighted Performance Scores on Specific Attributes ................................50

Table 10. Four Destinations' Weighted Performance Scores on Main Factors ...................................... 51

Table 11. Four Destinations' Overall Weighted and Non-weighted Performance Scores ......................53

Table 12. Comparison Weighted Performance and Non-weighted Performance.................................... 54 


\section{List of Figures}

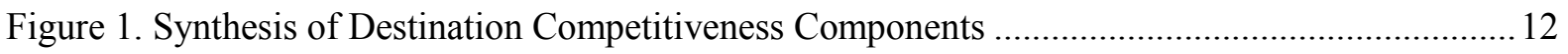

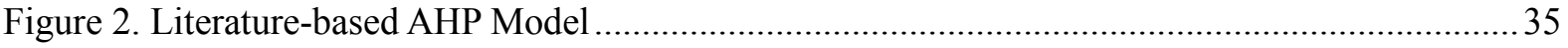

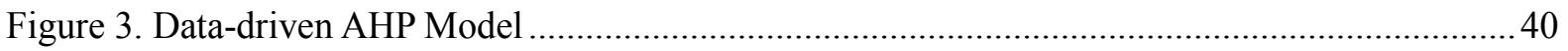

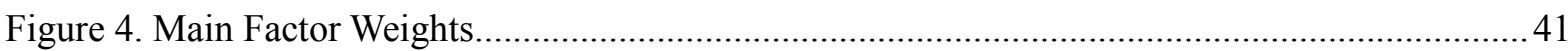

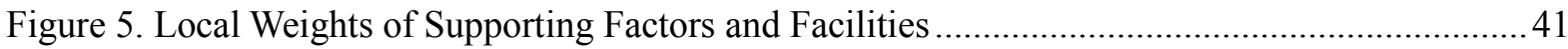

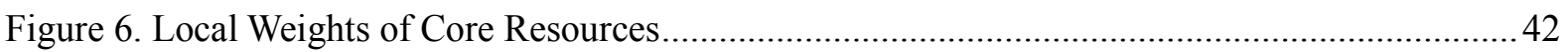

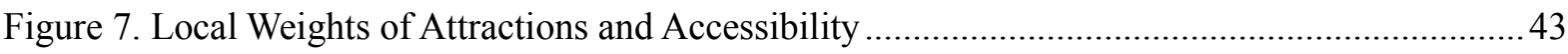

Figure 8. Local Weights of Qualifying and Amplifying Determinants .................................................. 44

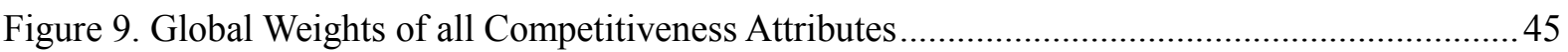

Figure 10. Final Model of Destination Competitiveness Evaluation ..................................................52

Figure 11. The Flow of Destination Competitiveness Management ...................................................... 61 


\section{Chapter 1. Introduction}

"In an ever more saturated market, the fundamental task of destination management is to understand how a tourism destination's competitiveness can be enhanced and sustained. There is thus a strong need to identify and explore competitive (dis)advantages and to analyze the actual competitive position" (Gomezelj \& Mihalič, 2008, p. 294). Obviously, it is worthwhile for destinations to focus attention and limited resources on those attributes that are likely to have the greatest beneficial impact (Crouch, 2011).

\section{Statement of the Research Problem}

Destination competitiveness has been examined from the perspectives of management in previous studies (Crouch 2000; Osmanković, Kenjić, \& Zrnić, 2010; Ritchie \& Crouch, 1999). In these cases, emphasis was put on the point of view of experts and industry practitioners, focusing on what destinations can do better to cater to tourists. Tourists are believed to be the proper audiences who can genuinely reflect the performance of tourism attributes because they have experienced the destinations they have visited. Tourists' perceptions of quality and overall performance play a significant role in determining repeat visits or positive word-of-mouth recommendation (Kozak \& Rimmington, 1999), and thus their opinions are worthy of study. However, the tourists' perspective of destination competitiveness has not been widely studied.

Another problem with the majority of existing competitiveness studies was that the attributes affecting competitiveness were measured without the use of attribute weights. Not all attribute are equally important in terms of their contributions to a destination's competitiveness. While some scholars have recognized the critical importance of weighting 
competitiveness attributes, they have let visitors rate the importance of each attribute on Likert type scales (Enright \& Newton, 2005; Kim, Guo, \& Agrusa 2005). Simply allocating weights is problematic because the relative importance is unknown and the consistency of respondents' ratings is not detected. Respondents might conflict with their own rating. For instance, individuals who give high points to beautiful scenery might conflict with themselves by giving low points to natural attractions, but this is not easily noticed by researchers. With the method of Analytic Hierarchy Process (AHP), researchers can detect inconsistencies of responses and know the reliability of their measurement (Czaja, Schulz, Lee, \& Belle, 2003).

AHP is a classical multi-criteria decision making (MCDM) tool, in which all factors affecting decision making are structured in a tree hierarchy and assigned weights. AHP has received increasing attention in the literature. Apart from decision-making process, AHP has been effectively used to address complex assessment, evaluation, and planning issues in a variety of areas (Alphonce, 1997; Chiang \& Lai, 2002; Czaja et al., 2003; Frei \& Harker, 1999; Ishizaka \& Labib, 2011; Jaber \& Mohsen, 2001; Kwak \& Lee, 2002; Ramanathan, 2001; Schniederjans \& Wilson, 1991; Suwignjo, Bititcj, \& Carrie, 2000; Troutt \& Tadisina, 1992; Viswanadhan, 2005; Viswanadhan, 2009; Yedla \& Shrestha, 2003).

West Virginia State is located in the east of United States (US), bordered by Virginia to the southeast, Kentucky to the southwest, Ohio to the northwest, Pennsylvania to the north, and Maryland to the northeast. As a tourism destination, it is marketed and nicknamed Wild and Wonderful West Virginia. The development of travel and tourism has great impacts on the State's economy development. As recorded in the Economic Impact of Travel on West 
Virginia (Dean Runyan Associates, 2013), visitors' travel spending has increased by $6.3 \%$ since 2000, which significantly contribute to the increase of jobs, local and state government revenues in the State. But compared to its neighboring states, the tourism impact in the State seems very small. U.S. Travel Association (2012) recorded that WV State's neighboring states had much bigger economic impact in terms of visitor spending, tax receipts, and employment. This should bring the attention of destination management and investigate some important phenomena behind the scene.

U.S. Travel Association (2014) made the forecasts for U.S. travel. In the forecast report, both U.S. domestic business and leisure travel are projected to grow at a steady rate from 2014 to 2017 while leisure travel will be having higher growing rate than business travel. Is West Virginia competitive for the future market that is promising as forecasted in this report?

The purpose of this study is to apply AHP to evaluate West Virginia's resource-based destination competitiveness, identify the tourism strengths and weaknesses of the State, and investigate if the AHP method makes a significant difference in evaluation results compared to the non-weighted method.

\section{Research Questions}

The study addresses the following research questions.

1. What is the proper model to evaluate West Virginia' tourism competitiveness?

2. What are the most and least important attributes for West Virginia's tourism competitiveness?

3. What are the strengths and weaknesses of West Virginia as a tourism destination compared to neighboring competitors? 
4. What is West Virginia's overall competitive position in relation to its neighboring competitors?

5. Does the AHP method make a significant difference in destination competitiveness evaluation compared to the non-weighted method?

\section{Delimitations}

\section{Analytic hierarchy process}

While destination evaluation can be achieved using a variety of methods, the current study used AHP. Conventionally, competitiveness attributes are not assigned weights, assuming that attributes are equally important in the evaluation process. But in reality, not every attribute equally contributes to destination competitiveness. AHP allows researchers to derive weights for each attribute involved in the evaluation process, so it is an ideal tool for destination competitiveness evaluation.

\section{Study participants}

Data to measure destination competitiveness could be collected from various groups of people, such as residents, excursionists, tourists, or industry experts. However, this study examined destination competitiveness from both experts and tourists. Experts were used to represent the supply side of destination. They determined the importance of the different attributes to destination competitiveness. Tourists were chosen to represent the demand side, and they evaluated a destination's performance. The demand side was confined to tourists and excluded excursionists because tourists stay longer and therefore they know more about the destination to evaluate its performance. Destination management practitioners were chosen to represent the management side because they are acquainted with the tourism industry in the State and are more qualified to identify the attributes that define their destination's 
competitiveness.

In this study, executive directors from Convention and Visitors Bureaus (CVB) were asked to do pairwise comparison to help the author derive weights for attributes. People may argue that what management thinks is important might not be important to tourists. This could be true, but using tourists to derive weights is inappropriate for two reasons. First, tourists might give imprecise information since they are not knowledgeable about the concept of destination competitiveness. Second, the survey instrument using AHP method was very lengthy in this study, so the author had concern that tourists would not be patient enough to fill out both weighting survey and performance survey. Forcing them to do so would have resulted in low response rate and/or more unusable surveys. Taking these factors into consideration, asking management practitioners to derive weights for attributes seemed appropriate.

\section{Resource-based competitiveness}

While there are many aspects of destination competitiveness that could be studied, such as environmental competitiveness (Mihalič, 2000), market competitiveness (Hassan, 2000), this study is focused on the evaluation of resource-based competitiveness for two reasons. First, resources are the foundations upon which tourism destinations are built. Core resources are one of fundamental reasons why visitors choose one destination over another (Ritchie \& Crouch, 2003), and thus resource-based competitiveness is worthy of study.

Second, while resource-based competitiveness has been widely studied in the business field, resource-based destination competitiveness has not been extensively studied in the literature.

\section{Definitions}


The following definitions provide insight into the purpose of this study.

Tourism destination: There is not much research distinguishing tourism destination from tourist destination, indicating that the two terminologies are interchangeable. Beirman (2003) defined a tourist destination as a country, state, region, city, or town which is marketed for tourists to visit. This study adopted Berman's definition but destination was defined at the state level.

Tourists: Tourists are people whose activity involves a stay away from the usual place of residence for at least one night (Leiper, 1979). For this study, tourists are defined as visitors who travel to and stay for at least one night in a tourism destination.

Destination competitiveness: The review of literature does not generate a universally acceptable definition on destination competitiveness. For this study, it refers to a tourism destination's relative superiority of the performance of its tourism attributes to other destinations as perceived by tourists. 


\section{Chapter 2. Literature Review}

In this chapter, the theoretical foundations of destination competitiveness are reviewed along with the various models and methods used to evaluate destination competitiveness.

\section{Definition of Competitiveness}

Competitiveness in tourism is a notion borrowed from economics where the concept of competitiveness has been widely studied at the national level. Scott and Lodge (1985, p. 3) defined national competitiveness as “a country's ability to create, produce, distribute, and /or service products in international trade while earning rising returns on its resources". Newall (1992, p. 1) described competitiveness as producing more and better quality goods and services that are marketed successfully to consumers at home and abroad, and that it speaks directly to whether a nation's economy can provide a high and rising standard of living for their children and grandchildren. Sustainability is the core of the definitions (Ritchie \& Crouch, 2003).

The concept of competitiveness has long been studied at the national level (macro perspective) and industry level (micro-perspective). Crouch and Ritchie (2000) stated that competitiveness is a country's ability to create added value and thus increase the national wealth by managing assets and processes, attractiveness, aggressiveness and proximity. Popular tools used to assess tourism competitiveness at national level include Porter's diamond model (Porter, 1990), World Competitiveness Yearbook's four categories (Kao, Wu, Hsieh, Wang, Lin, \& Chen, 2008), and the competitive index of the World Economic Forum (WEF). At the industry level, Cracolici and Nijkamp (2009) defined competitiveness as a 
unit's both qualitative and quantitative superiority over its real or potential competitors. Performance superiority was addressed in these two definitions.

Researchers have endeavored to find a suitable definition of destination competitiveness. Dwyer, Forsyth, and Rao (2000) examined destination competitiveness based on price differentiation. They defined competitiveness as "a general concept that encompasses price differentials coupled with exchange rate movements, productivity and qualitative factors affecting the attractiveness of a destination" (Dwyer et al., 2000, p. 9). Hassan (2000) defined destination competitiveness as a destination's ability to create and integrate value-added product to maintain its competitive edge over competitors, while sustaining its resources. In line with Hassan's definition, the definition proposed by Dwyer and Kim (2003) suggests that destination competitiveness is associated with a destination's ability to deliver goods and service better than other destinations do. Early studies recognized that competitiveness is both a relative and multidimensional concept (Scott \& Lodge, 1985; Crouch \& Ritchie, 1999). Overall, while there is no universally acceptable definition of destination competitiveness, it is critical to note that the definition of destination competitiveness consists of several major components: a destination (producer), goods and services/ tourism attributes (product), tourists/visitors (receiver), consumption reflection (tourist/visitors' after-trip feeling), and comparison objects (other destinations). The definitions of (destination) competitiveness addressed two main points: sustainability, and superiority. For the purposes of this study, destination competitiveness is defined based on the relative superiority of a destination's performance on a set of tourism attributes in comparison to other destinations, as perceived by tourists. 


\section{Competitiveness Evaluation Models}

Since the 1990s, researchers have developed several conceptual models to assist in evaluating destination competitiveness. The composition of the existing models exhibits the breadth and complexity of destination competitiveness components and structures as described below.

Porter (1990) introduced a well-known diamond model to examine industry competitiveness. In this model, four broad attributes of a nation fundamentally determine the competitiveness of an industry or a company: (a) factor conditions, referring to the supply of skilled labor or infrastructure, (b) demand conditions, (c) related and supporting industries, (d) firm strategy, structure, and rivalry. Chon and Mayer (1995) drew upon Porter's diamond competitiveness model in their case study of Las Vegas and included five main factors: appeal, management, organization, information, and efficiency.

De Keyser and Vanhove (1994) suggested that evaluation of competitiveness should be based on five factors: tourism policy, macro-economics, supply, transport, and demand factors. This model was adopted later in two competiveness studies of Slovenian tourism (Gomezelj \& Mihalič, 2008; Sirse \& Mihalic, 1999).

Enright, Scott, and Dodwell (1997) proposed an alternative framework that divided drivers of competitiveness into six categories: inputs, industrial and consumer demand, inter-firm competition and cooperation, industrial and regional clustering, internal organization and strategy of firms and institutions, and social structures and agendas.

Crouch and Ritchie (1999) postulated a conceptual model in which destination competitiveness is determined by four groups of factors: core resources and attractors, supporting factors and resources, destination management, and qualifying determinants. The 
conceptual model included a total of 19 attributes. The conceptual model of Crouch and Ritchie (1999) was meant to be relevant to any destination and tourism market as all potentially important attributes were included. In 2003, Ritchie and Crouch expanded the original conceptual model by adding an additional factor: destination policy, planning and development. Richie and Crouch's (2003) new conceptual model comprises of 36 indicators grouped under the five categories as aforementioned. It is worth noting that this model also includes competitive (micro) environment and global (macro) environment as factors influencing a destination's competitiveness.

Dwyer and Kim (2003) proposed a destination competitiveness model consisting of seven main components similar to those proposed by Ritchie and Crouch $(1999 ; 2003)$. The components included: endowed resources, created resources, supporting factors, destination management, situational conditions, demand factors, and market performance.

Dwyer, Livaic and Mellor (2003) adopted this model (Dwyer \& Kim, 2003) to evaluate the competitiveness of Australia as a tourism destination. Enright and Newton (2004) added generic business factors of competitiveness to the list of factors that determine destination's competitiveness.

Osmanković et al. (2010) claimed that competitiveness level is determined by productivity of products and services as well as the efficiency with which they are produced. They asserted that increasing efficiency, differentiating product, improving product quality, or by means of influencing demands are ways to improve competitiveness.

The World Economic Forum (WEF) has used a competitiveness index to evaluate destination competitiveness at the national level since 2004. The WEF index is derived from 
a set of 14 pillars categorized into three subgroups: (a) travel and tourism regulatory framework, (b) travel and tourism business environment and infrastructure, and (c) travel and tourism human, cultural and natural resources. This model is more applicable at the national level than it is at regional or local levels. Lall (2001) evaluated the WEF index, and eventually detected two major deficiencies. That is, the two underlying assumptions of market efficiency and friendly policy intervention were not met. Also, the model's broad definition of competitiveness diverts from its legitimate focus on direct competition between countries (Lall, 2011, p.1519).

Tseng and Chen (2013) constructed a destination competitiveness evaluation model for city destinations in Taiwan. Drawing upon previous studies and focus groups, they utilized 27 items loading on five main categories: core resources and attractions, tourists' service facilities, supporting factors, destination management, and situational conditions.

A synthesis of the past studies reveals that destination competitiveness is affected by two main sources of factors (Figure 1): internal and external. The former source refers to internal management and destination resources (i.e., natural, cultural or manmade kinds). And the latter focuses on external influences from macro and/or micro environments. 


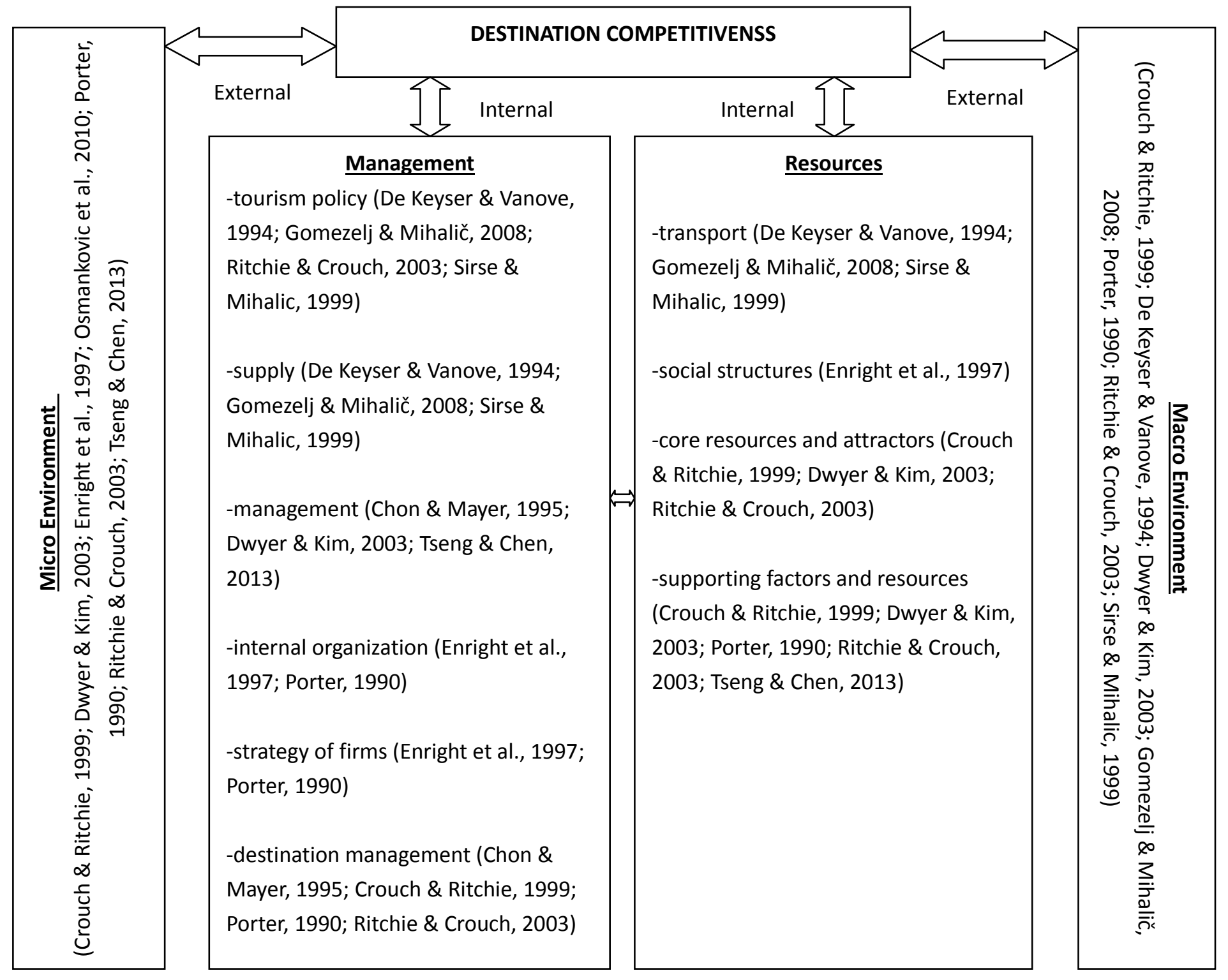

Figure 1. Synthesis of Destination Competitiveness Components

As the literature review illustrates, destination competitiveness is determined and influenced by a large number of factors. The evaluation of a destination's competitiveness is not an easy task due to the fact that most of the factors are difficult or impossible to capture accurately. Also, attributes that apply in one destination may not be applicable in another destination. Some of the previous studies have focused solely on one variable considered as a crucial component to destination competitiveness. The most frequently studied variable is 
price/cost, considered as one of the important factors that influence destination competitiveness (Azzoni \& Menezes, 2009; Dwyer et al., 2000).

While it is challenging to identify all the key variables that are critical to destination competitiveness, researchers have made tremendous efforts to simplify the process. Ritchie and Crouch's (2003) study revealed that core resources and attractors are the fundamental reasons why potential visitors pick one destination over another. Supporting factors, such as accessibility, infrastructure, and hospitality among others provide a foundation for successful tourism. With the purpose of identifying the most important factors in Ritchie and Crouch's (2003) conceptual model, Crouch (2011) identified the top 10 determinant attributes of destination competitiveness using AHP including physiography and climate, special events, mix of activities, culture and history, superstructure, accessibility, awareness/image, entertainment, infrastructure, and positioning and branding (Table A1). In addition to the top 10 determinant attributes, location, cost value, and safety and security were also identified as very important attributes (Table A1).

The current thesis drew upon Ritchie and Crouch's (2003) and Crouch's (2011) studies to construct a literature-based AHP model for destination competitiveness evaluation of West Virginia. There were several reasons for using Crouch's (2011) findings as the basis for this study's literature-based model. First, in Crouch's (2011) study, data were collected from individuals with different levels of experience and expertise on the topic of destination competitiveness, which highly decreased the possibility of heavily skewed data that could bias estimation. Second, individuals surveyed were located in different parts of the world and they were either working for destination management organizations (DMOs) on management 
issues such as marketing, administration, or working as academic researchers doing research in one or more areas of destination management and marketing. Although their perceptions about what attributes determine destination competitiveness might vary to some extent, their pooled input could be closer to truth. Third, the computation of the attribute determinacy measure was rigorous (Crouch, 2011, p. 37). Last, global weights were derived to enable direct comparison across all 36 competitiveness attributes. This study excluded positioning and branding attributes in Ritchie and Crouch's (2003) conceptual model because that performance rating of tourism attributes for this study was designed for tourists who are not in a position to evaluate destination internal management activities ( personal communication with Crouch, 2014).

Since the concept of destination competitiveness was borrowed from economics, it is important to also review business research on competitiveness. Wernerfelt (1984, p.171) stated that, for a firm, resources and products are two sides of the same coin. Resources mean anything "that could be thought of as a strength or weakness of a given firm" (Wernerfelt, 1984, p.172). Similarly, for a destination, tourism resources and products (tourism experiences) are the two significant components. Just as resources are used to produce products, tourism resources are the foundations for valuable tourism experiences. A firm's property, including resources and capabilities, contribute to sustained competitive advantage if they are valuable, rare, and not substitutable (Barney, 1991). Ambastha and Momaya (2004) stated that assets and processes within an organization are the sources of competitiveness. The assets and processes correspond to resources and capabilities aforementioned.

Resource-Based View (RBV) is a popular and widely acknowledged framework to 
evaluate business competitiveness. According to RBV, resources are the core of competitiveness. With its powerful and rigorous theoretical perspective, a lot of business studies have been embedded in the theory of RBV (Peng, 2001).

As discussed earlier in this section, traditional models of destination competitiveness evaluation encompass a variety of internal and external aspects. While all the factors affecting destination competitiveness are worthy of attention for managers and evaluators, it is more meaningful to emphasize on the resource-based competitiveness for two main reasons.

First, resources are what make the destination appealing and unique so that they are the core of a destination and worth of study. Second, resources depreciate over time, so management needs to understand which resources make their destination competitive in order to better manage what attracts visitors sustainably. However, there are not many resource-based destination competitiveness studies in the literature. Therefore, this study contributes to the body of knowledge of this realm by using resource-based view to evaluate a destination's tourism competitiveness.

\section{Competitiveness Evaluation Methods}

Destination competitiveness evaluation could be broadly divided into two main themes: model building/ indicator construction and corresponding critique, and empirical measurement of destination competitiveness. The former tends to emphasize qualitative methods (Dwyer \& Kim, 2003; Lall, 2001) and the latter adopts quantitative or mixed methods (Enright \& Newton, 2004; Kao et al., 2008; Lee, Mogi, \& Kim, 2008; Roberts \& Stimson, 1998; Tseng \& Chen, 2013)

While many scholars have realized the importance of studying relative importance of 
destination attributes in competitiveness evaluation, the methods applied to establish the relative importance of the attributes are quite different. Enright and Newton (2004) used Importance-Performance Analysis (IPA) where respondents were asked to rate the importance of each factor in contributing to competitiveness and then assess Hong Kong's competitiveness in relation to its competitors. Tseng and Chen (2013) used simple descriptive analyses (mean, and standard deviation) to show the importance of tourism competitiveness attributes.

It is good to realize the need to study relative importance of tourism attributes, but simply allocating weights to attributes as mentioned above is not sufficient because the relative importance of each attribute remains unknown. But, relative importance of categories of attributes (e.g., how important is category 1 compared to category 2 ) and relative importance of attributes within each category (e.g., how important is attribute A compared to attribute B within category 1) are crucial aspects to address to achieve accurate destination competitiveness evaluation. Dwyer and Kim (2003) asserted that relative importance of the different dimensions of competitiveness should be examined.

To derive relative importance of attributes, a more rigorous method was used by Kao et al. (2008). While they studied national competitiveness instead of tourism destination competitiveness, the logic can be applied to tourism. To better understand the approach they took in their investigation, details are provided below. In their study, 10 countries were evaluated in terms of their national competitiveness. The national competitiveness was deconstructed into four measurable primary criteria: economy, technology, human resources, and management. There were a total of 16 attributes spread across the four primary categories. 
Economy category included four indicators, which were called secondary factors, namely, domestic economy, government, international trade, and finance. Technology measurement items involved infrastructure, information technology, research and development, and technology management. Human resources was measured by quantity and quality of human resources, labor cost, and labor legislation while management was examined by factors including managers' competence, corporate culture, industry integration, international operation, and productivity. Each secondary factor was measured with a set of criteria (different measurement items).

In order to derive weights for both primary and secondary factors, Kao et al (2008) introduced two types of weights: a priori weights and a posteriori weights. Weights extracted from surveys of experts were called a priori weights. Weights computed from data collected from visitors were called a posteriori weights. Both a priori weights and a posteriori weights were applied to evaluate the 10 Asian countries' national competitiveness. For the purpose of this thesis, only a priori weights were used. As described in their study, to derive a priori weights, experts were asked to allocate scores to secondary factors in a range 0 and 100 . The ratio of the score of a secondary factor to the total score of all secondary factors represented the weight of that secondary factor (e.g., if secondary factor A scored 25 and the total score for all secondary factors was 200 , the weight for the factor A would be .125). Weights for primary factors were derived in the same manner.

While the approach Kao et al. (2008) utilized was more rigorous than other ones introduced earlier (Enright \& Newton, 2004; Tseng \& Chen, 2013), it was not without problems. First, they asked respondents to rate the performance of each criterion within 
secondary factors for three countries (respondents' own country and two other countries). If some respondents had not gone to the other one or two countries they were assigned to rate, then their ratings were not reliable. Second, this study only had weights for primary and secondary factors and no weights were derived for the criteria within each secondary factor, assuming that each criterion was equally important, but, in reality, this could not be true. Last but not least, the method used to derive weights was not ideal for a statistical reason: The scores are absolute values with the potential to be extremely large or small, which could have undue influence on the total scores and thus distort the weights for each individual factor. For instance, if an extremely large (small) score existed in a group of secondary factors, weights of the other secondary factors with smaller (larger) scores in that group would tend to be smaller (bigger) than it should be without the existence of extreme value.

AHP is superior to Kao el al.'s (2008) method because it assigns weights to the importance of factors and the derived weights are not easily influenced by extreme values. The usefulness of AHP as an evaluation tool was supported in Lee et al. (2008) study in which they applied AHP to evaluate Korea's competitiveness as a developer of hydrogen energy technology. Since there are few competitiveness studies utilizing AHP in destination competitiveness evaluation, this study contributes to the body of knowledge in this area by evaluating destination competitiveness with the method of AHP.

\section{Analytic Hierarchy Process (AHP)}

Analytic hierarchy process (AHP) is a multi-criteria decision making (MCDM) technique. It is believed to be "of particular value when subjective, abstract or non-quantifiable criteria are involved in the decision" (Saaty, 1988, p. 110). AHP is a 
three-step process. First, identify and organize the study objective, evaluation criteria, and alternatives into a hierarchy. Second, conduct pairwise comparisons between elements at each level, followed by a synthesis "using the solution algorithm of the results of the pairwise comparisons over all the levels" (Saaty, 1988, p.110). Finally, the relative importance of evaluation criteria calculated from step two are used to establish the relative performance of alternatives. Take destination competitiveness evaluation as an example. First, evaluators need to know that their objective is to identify a tourism destination's competitive position among other competitors. Second, they need to know what factors determine destination competitiveness. Third, since relevant factor are not equally important, they will need to figure out the relative importance of each factor using pairwise comparison. With the relative importance of the factors, they are able to establish the relative performance of each destination by summing up the products of each factor and its corresponding performance rating. The final result will give them some numerical numbers; whichever destination has the highest performance score is the most competitive destination.

The core of the AHP is weighting criteria and indicators with pairwise comparison. The strength of this method lies in the fact that it allows researchers to inspect the consistency among respondents' judgment during pairwise comparison. Before weights are applied, inconsistency ratio are to be checked because weights will make sense only if derived from consistent or near consistent matrices ( Ishizaka \& Labib, 2011)

Due to its simplicity and rigorousity, AHP has received increasing attention in the literature and has been effectively used to address complex issues in a variety of areas including but not limited to: information system selection (Schniederjans \& Wilson, 1991), 
merit salary increase decision support system design (Troutt \& Tadisina, 1992), resources allocation (Alphonce, 1997), performance measuring (Frei \& Harker, 1999; Suwignjo et al., 2000), water resources evaluation (Jaber \& Mohsen, 2001), environmental impact assessment (Ramanathan, 2001), indoor environment assessment (Chiang \& Lai, 2002), planning (Kwak \& Lee, 2002), environmental transport system selection (Yedla \& Shrestha, 2003), wind-power location choice (Czaja et al., 2003), education quality indicator (Viswanadhan, 2005; Viswanadhan, 2009), and much more extensive areas (Ishizaka \& Labib, 2011).

From the applications listed above, it is evident that AHP is an efficient tool to solve decision problems, and evaluation/assessment issues where several criteria and many indicators are involved. In the tourism sector, many studies emerged that adopted this method to solve selection problems or evaluation issues. Examples include tourism natural attraction evaluation (Deng, King, \& Bauer, 2002), convention site selection (Chen, 2006), hotel location selection (Chou, Hsu, \& Chen, 2008), online personalized attractions recommendation system (Huang \& Bian, 2009), and tourists destination preferences evaluation (Hsu, Tsai, \& Wu, 2009).

Destination competitiveness evaluation is a multi-criteria assessment process where criteria are subjective, somewhat abstract or unquantifiable. It is conducive to apply AHP in the process for it has long been used in evaluations of similar complexity in the literature. However, not many tourism destination studies have been identified in this aspect. The most recent destination competitiveness study applying AHP used the method to determine relative importance of competitiveness attributes (Crouch, 2011). However, Crouch (2011) did not use the method to evaluate a specific destination, nor compare the methodology to traditional 
evaluation methods. This thesis goes further to: propose an AHP model to evaluate destination competitiveness, derive weights for tourism attributes, use the weights to evaluate several destinations' tourism competitiveness, and examine the competitiveness evaluation outcome difference resulting from application of AHP method compared to the traditional non-weighted method. 


\section{Chapter 3. Methodology}

In this chapter, details are provided about the methodology used in this study, including two stages of data collection, applied models, and specific analysis methods.

\section{Data Collection}

Data collection for this study involved two stages. The first stage was primary data collection from visitors. The second stage was data collection from tourism practitioners/experts to derive weights for attributes.

\section{First stage data collection}

Visitors to West Virginia were the targeted sample population in the first stage data collection. Data was collected in summer 2012 at two rest areas (one located on the west bound lane of I-64 and the other one on the west bound lane of I-68) in West Virginia as part of a larger competitiveness study.

Convenience sampling was used in this study. Visitors were approached at the two rest areas and asked if they would be willing to participate after receiving an explanation of the purpose of the study. Questionnaires were either self-administered or face-to-face depending on respondents' preference. The questionnaire included the following four main components.

(1) General travel background information including visitors' origin, repeat visit, travel group size, length of stay, and travel expenditure.

(2) Competitiveness section including comparing West Virginia's performance to a recently visited Eastern US destination on a list of competitiveness attributes (Table 1) from 1 (poor) to 5 (excellent). 
Table 1

Destination Competitiveness Attributes Used in the First Stage Data Collection

\begin{tabular}{llll}
\hline Order & Attributes & Order & Attributes \\
\hline 1 & Hospitality \& friendliness of residents & 14 & Value for money in shopping items \\
2 & Safety and security & 15 & Local transportation efficiency \\
3 & Cleanliness & 16 & Availability of adventure-based activities \\
4 & Variety of activities to do & 17 & Historical sites \\
5 & Accessibility of destination & 18 & Nature-based activities \\
6 & Well marked roads/attractions & 19 & Visitor accessibility to attractions \\
7 & Availability of activities for children & 20 & Special events \\
8 & Shopping facilities & 21 & Well-known landmarks \\
9 & Good weather/climate & 22 & Conveniently located \\
10 & Value for money in tourism experience & 23 & Availability of tourist information \\
11 & Road conditions & 24 & Communication facilities \\
12 & Variety \& quality of accommodation & 25 & Interesting architecture \\
13 & Variety \& quality of restaurants & 26 & Dedicated tourism attractions \\
\hline
\end{tabular}

(3) A total of 17 motivation measurements were also included in the survey including: relax, enjoy the good weather, have fun, forget day to day problem, seek adventure, engage in sporting activities, get closer to nature, be active, mix with other tourists, get away from home, visit historical sites, reconnect with family and friends, increase knowledge of new places, get emotionally and physically refreshed, escape from a busy life, rediscover self, and indulge self/family.

(4) Visitors demographics, such as gender, age, income level, education level.

\section{Second stage data collection}

In this stage, data was collected from executive directors from West Virginia

Convention and Visitors Bureaus (CVBs).

\section{Participants}

A list of $28 \mathrm{CVB}$ executive directors was targeted to participate in the study. Three of these directors did not provide their email address publicly, so only 25 of them were 
contacted through emails on April 25, 2014. A cover letter (Appendix B) and survey (Appendix C) were added as attachments in the emails sent. Of the contacted directors, five were not reachable due to non-functional listed emails, resulting in 20 directors with valid emails. Following Dillman's (1978) survey approach, approximately a week later (May 5, 2014), a follow-up cover letter (Appendix D) along with the original survey was sent again to each of the $20 \mathrm{CVB}$ directors to remind them about the study. After the follow-up emails, four surveys were completed and returned. On May 9, as indicated in the follow-up cover letter, follow-up phone calls were made to the remaining 16 directors who had not responded. Two indicated that they wanted face-to-face interaction, three preferred paper surveys, and the reminder promised to complete and return the original survey by email. On May 12th, paper surveys were mailed with "Thank You" notes. The two face-to-face interviews were arranged and conducted on May 13 and May 14, 2014. A total of 10 surveys were completed by May 25,2014 , representing a $50 \%$ response rate.

\section{Instrument}

The survey used in this stage was based on the completion of the first research question: what is the proper model to evaluate West Virginia' tourism competitiveness? Respondents were asked to make pairwise comparisons among all competitiveness attributes used in the visitor survey.

An initial pairwise comparison survey, consisting of five blocks of pairwise comparisons and a section to collect demographic information, was designed and pretested among five graduate students at West Virginia University, four from the Recreation, Parks, and Tourism Resources program, and the other one from another department. Based on 
pretest feedback on survey layout, readability, and ease of understanding, the instrument was finalized (Appendix C).

\section{Data Analysis}

The following five sub-sections illustrate the analyses conducted to answer the five research questions proposed in this study. Each section starts with the research question followed by a specific analysis procedure.

\section{What is the proper model to evaluate West Virginia' tourism competitiveness?}

Two models were developed and compared. The first model constructed was a literature-based model and the second a data-driven model. The literature-based model was developed based on Ritchie and Crouch's (2003) conceptual model and the main findings from Crouch's (2011) study. The data-driven model was created by applying factor analysis on the attributes used in tourists' survey (Table 1). Principal component was the extraction method with varimax rotation. Factors were retrieved based on Eigenvalue greater than 1.00 criterion. One of the two models was used in the subsequent analysis once it was identified as the best model that could be used to evaluate West Virginia's tourism destination competitiveness.

\section{What are the most and least important tourism attributes for West Virginia's}

\section{destination competitiveness?}

To answer this question, a three-step process was conducted. 
(1) The first step was to calculate relative importance of tourism attribute $m$ over attribute $n$, which was denoted as $a_{m n}$. The relative importance values of $a_{m n}$ was computed by the geometric mean of equation defined as

$$
a_{m n}=p \sqrt{\prod_{k=1}^{p} a_{m n}^{k}}
$$

Here, $\mathrm{p}$ is the total number of participants who rated the relative importance of attribute $m$ over attribute $n$. Excel was used to calculate these values.

(2) Second, the relative importance values calculated in the previous steps were input in the Expert Choice software to calculate weight for each attribute, meanwhile inconsistency ratio $(\mathrm{CR})$ was examined in accordance with the rule that $\mathrm{CR}$ is considered acceptable when it is not bigger than .10 (Banai-Kashani, 1989; Bunruamkaew, 2012; Saaty, 1980; Wang, 2008). The weights derived in this process included local weights and global weights. The former referred to attributes' weights within a main factor and they were not comparable to other attributes' weights within another category. And the latter meant attribute weights across all factors and thus they are comparable, and these attributes weights are accumulated up to one.

(3) Third, after both local weights and global weights were derived, the most and least important attributes were presented by their global weights: the larger the global weight, the more important an attribute.

\section{What are the strengths and weaknesses of West Virginia as a tourism}

\section{destination compared to neighboring competitors?}

To answer this question, the following procedure was conducted. 
(1) Frequencies were run to identify other destinations tourists had recently visited in the eastern US. The top three mentioned destinations were chosen as West Virginia's potential neighboring competitors.

(2) New variables were created that denoted the weighted performance of the destination on each attribute in SPSS software by multiplying the rating of an attribute by its weight. Variable symbols are presented in Table E1.

(3) The weighted performances of destinations on each main factor were computed by summing the weighted performance of corresponding indicators under each factor.

(4) The means of destinations' performance on each attribute and factor were computed.

(5) The four destinations were ranked based on their performance on each attribute and factor. Attributes/factors with higher ranks were identified as strengths of a destination and those with lower ranks as weaknesses of the destination.

\section{What is West Virginia's overall competitive position in relation to its neighboring}

\section{competitors?}

To answer this question, three steps were conducted.

(1) All factors that affect destination competitiveness were structured in a hierarchy. The apex of the hierarchy was the goal of evaluating destination competitiveness. The first layer of the hierarchy represented the main factors determining destination competitiveness and the second layer was constructed with attributes within each main factor. The four destinations (West Virginia and its three identified neighboring competing States) were arranged at the bottom of the hierarchy to represent the destinations evaluated (Figure 3, \& Figure 11).

(2) The overall performance of each destination was computed. 
(3) After the overall performance for each destination was computed. The four destinations were ranked. West Virginia's overall competitiveness position in relation to the neighboring competitors was established. The four destination's overall non-weighted performance scores were also computed to compare with the weighted scores.

Does the AHP method make a significant difference in destination competitiveness evaluation compared to the non-weighted method?

This question was answered by testing a null hypothesis: there is no significant difference in evaluation results between AHP and non-weight method. The test was conducted on the following factors:
A. supporting factors and facilities
B. core resources
C. attractions and accessibility
D. qualifying and amplifying determinants
E. overall performance of a destination

The following are the steps taken to test the null hypothesis:

(1) A set of new variables were computed to denote non-weighted scores of each factor by averaging the scores of attributes under a factor. Variable symbols are provided in Table E2.

(2) Paired-sample $t$ test was run with significant level of .05. 


\section{Chapter 4. Results}

This chapter consists of seven sections. Tourists' demographic and travel characteristics are provided in the first section, followed by information about responding CVB directors in the second section. Results for each research question are presented in the remaining five sections.

\section{Tourists}

A total of 891 usable surveys were collected of which 336 respondents were tourists who had stayed for at least one night in the State. The 336 tourists were the only ones included for further analysis in this study. Very few $(2.5 \%)$ of the tourists were international tourists and the majority were from other states in the United States (Table 2). There were about the same number of females as males. About $68 \%$ of the respondents were aged above 50. Approximately, the respondents had gross annual income of $\$ 75,000$ and higher. About $34 \%$ of the respondents had an undergraduate degree and more than $45 \%$ had a graduate degree. More descriptive information about tourists is presented in Table 2. 
Table 2

Tourists Characteristics

\begin{tabular}{|c|c|c|}
\hline Attributes & Frequency & Percentage (\%) \\
\hline \multicolumn{3}{|l|}{ Nationality $(N=366)$} \\
\hline National/domestic & 357 & 97.5 \\
\hline International & 9 & 2.5 \\
\hline \multicolumn{3}{|l|}{ Residence $(N=355)$} \\
\hline West Virginia residents & 44 & 12.4 \\
\hline Non-residents of West Virginia & 311 & 87.6 \\
\hline \multicolumn{3}{|l|}{ Gender $(N=352)$} \\
\hline Male & 174 & 49.4 \\
\hline Female & 178 & 50.6 \\
\hline \multicolumn{3}{|l|}{$\operatorname{Age}(N=352)$} \\
\hline $18-30$ & 36 & 10.2 \\
\hline $31-50$ & 77 & 21.9 \\
\hline $51-70$ & 193 & 54.8 \\
\hline Over 70 & 46 & 13.1 \\
\hline \multicolumn{3}{|l|}{ Income $(N=325)$} \\
\hline Below $\$ 25,000$ & 25 & 7.7 \\
\hline$\$ 25,000-\$ 45,000$ & 43 & 13.2 \\
\hline$\$ 46,000-\$ 65,000$ & 66 & 20.3 \\
\hline$\$ 66,000-\$ 75,000$ & 33 & 10.2 \\
\hline$\$ 76,000-\$ 100,000$ & 72 & 22.1 \\
\hline Above $\$ 100,000$ & 86 & 26.5 \\
\hline \multicolumn{3}{|l|}{ Education $(N=351)$} \\
\hline Less than high school & 6 & 1.7 \\
\hline High school diploma or equivalent & 66 & 18.8 \\
\hline Undergraduate & 119 & 33.9 \\
\hline Graduate & 160 & 45.6 \\
\hline
\end{tabular}

About $47 \%$ of the respondents had previously visited West Virginia in the past two years. On average, these tourists planned to stay 6.17 nights in the State. Average group size was 4.72 people and average budget was about $\$ 250 /$ person/trip.

With regard to travel motivations, approximately two thirds of the respondents were motivated by their need to be active, and reconnect with family or friends (Table 3). More than half of the respondents had the motivation of seeking adventure and increasing their knowledge about new places. The majority of respondents were motivated to visit West 
Virginia to relax $(78.3 \%)$, have fun $(83.4 \%)$, get away from home $(69.5 \%)$, and get emotionally and physically refreshed (69.2\%). Overall, the top motivations (Table 3 ) were: to have fun $(M=4.29)$, to relax $(M=4.16)$, to get emotionally and physically refreshed $(M=$ 3.92), to get away from home $(M=3.91)$, to indulge self/family $(M=3.91)$, and to seek adventure $(M=3.88)$. Mix with other tourist and engaging in sport activities were the least motivating factors to visit the State (Table 3). More information about tourists' travel motivation is provided in Table 3 . 
Table 3

Tourists' Motivations to Visit West Virginia

\begin{tabular}{|c|c|c|c|c|c|c|}
\hline Motivations & $\begin{array}{c}\text { Disagree } \\
\text { Completely }\end{array}$ & Disagree & Neutral & Agree & $\begin{array}{c}\text { Agree } \\
\text { Completely }\end{array}$ & $\begin{array}{c}\text { Mean } \\
\text { (out of 5) }\end{array}$ \\
\hline Be active & $8.5 \%$ & $9.2 \%$ & $18.1 \%$ & $28.0 \%$ & $36.2 \%$ & 3.74 \\
\hline Mix with other tourists & $33.5 \%$ & $18.1 \%$ & $19.9 \%$ & $15.3 \%$ & $13.2 \%$ & 2.57 \\
\hline Reconnect with family and & $16.3 \%$ & $8.5 \%$ & $11.9 \%$ & $13.3 \%$ & $50.0 \%$ & 3.72 \\
\hline \multicolumn{7}{|l|}{ friends } \\
\hline Engage in sporting activities & $23.7 \%$ & $14.7 \%$ & $22.3 \%$ & $15.8 \%$ & $23.4 \%$ & 3.00 \\
\hline Visit historical sites & $12.2 \%$ & $12.6 \%$ & $31.1 \%$ & $21.3 \%$ & $22.7 \%$ & 3.30 \\
\hline Increase my knowledge of new & $11.1 \%$ & $10.4 \%$ & $22.1 \%$ & $33.6 \%$ & $22.9 \%$ & 3.47 \\
\hline \multicolumn{7}{|l|}{ places } \\
\hline Rediscover self & $14.0 \%$ & $15.1 \%$ & $28.8 \%$ & $17.3 \%$ & $24.8 \%$ & 3.24 \\
\hline Seek adventure & $8.9 \%$ & $10.7 \%$ & $24.6 \%$ & $25.7 \%$ & $30.0 \%$ & 3.57 \\
\hline Relax & $3.4 \%$ & $3.4 \%$ & $15.0 \%$ & $30.3 \%$ & $48.0 \%$ & 4.16 \\
\hline Have fun & $2.7 \%$ & $2.4 \%$ & $11.5 \%$ & $30.2 \%$ & $53.2 \%$ & 4.29 \\
\hline Forget day to day problem & $3.5 \%$ & $9.9 \%$ & $20.5 \%$ & $29.0 \%$ & $37.1 \%$ & 3.86 \\
\hline Enjoy the good weather & $2.7 \%$ & $4.8 \%$ & $29.2 \%$ & $29.6 \%$ & $33.7 \%$ & 3.87 \\
\hline Get closer to nature & $9.1 \%$ & $6.6 \%$ & $18.9 \%$ & $28.7 \%$ & $36.7 \%$ & 3.77 \\
\hline Get away from home & $7.6 \%$ & $4.8 \%$ & $18.0 \%$ & $28.0 \%$ & $41.5 \%$ & 3.91 \\
\hline Get emotionally and & $3.9 \%$ & $6.7 \%$ & $20.2 \%$ & $31.6 \%$ & $37.6 \%$ & 3.92 \\
\hline \multicolumn{7}{|l|}{ physically refreshed } \\
\hline Escape from a busy life & $4.6 \%$ & $8.5 \%$ & $23.2 \%$ & $21.8 \%$ & $41.9 \%$ & 3.88 \\
\hline Indulge self/family & $5.6 \%$ & $6.3 \%$ & $21.7 \%$ & $24.5 \%$ & $42.0 \%$ & 3.91 \\
\hline
\end{tabular}

\section{CVB Directors}

Eight West Virginia CVB executive directors completed and returned the survey through email and two other executive directors completed the surveys by face-to-face interviews. In total, 10 usable surveys were collected. There were five female directors and 
five male directors (Table 4). Two out of the 10 directors were younger than 40 . The average age for these directors was about 50 . Four of the directors had more than 15 -year-long work experience in West Virginia's tourism sector, and on average, the remaining six had about 6 years' experience in the tourism field in West Virginia. None of these directors had worked in other states' tourism industry. Six of the directors had earned a bachelor's degree, and two had graduate education. Descriptive information about the executive directors is provided in detail in Table 4. 
Table 4

CVB Directors' Characteristics

\begin{tabular}{|c|c|}
\hline Variables & Frequency \\
\hline \multicolumn{2}{|l|}{ Gender } \\
\hline Male & 5 \\
\hline Female & 5 \\
\hline \multicolumn{2}{|l|}{ Age } \\
\hline $18-30$ & 1 \\
\hline $31-40$ & 1 \\
\hline $41-50$ & 2 \\
\hline $51-60$ & 4 \\
\hline $61-70$ & 2 \\
\hline \multicolumn{2}{|c|}{ Years of work experience in tourism in West Virginia } \\
\hline $1-3$ & 2 \\
\hline 4-6 & 1 \\
\hline 7-9 & 2 \\
\hline $10-12$ & 1 \\
\hline 13-15 & 0 \\
\hline More than 15 & 4 \\
\hline \multicolumn{2}{|l|}{ Work experience in tourism from other states } \\
\hline Yes & 0 \\
\hline No & 10 \\
\hline \multicolumn{2}{|l|}{ Education level } \\
\hline High school diploma & 1 \\
\hline Undergraduate or post-secondary degree & 6 \\
\hline Graduate degree & 2 \\
\hline Other & 1 (Marketing College) \\
\hline
\end{tabular}

What is the proper model to evaluate West Virginia's tourism competitiveness?

\section{Literature-based AHP Model}

Based on Ritchie and Crouch's (2003) conceptual model and Crouch's (2011) studies

discussed in the Literature Review section, a literature-based AHP model was constructed.

The literature-based model (Figure 2) stated that destination competitiveness is determined

by a destination's supporting factors and resources, core resources and attractors, amplifying

and qualifying determinants. Within this model, supporting factors and resources is measured

by the attributes of infrastructure, accessibility and hospitality, core resources and attractors 
by physiography and climate, culture and history, mix of activities, special events, entertainment, and superstructures, and amplifying and qualifying determinants by awareness/image, location, safety and security, and value in money.

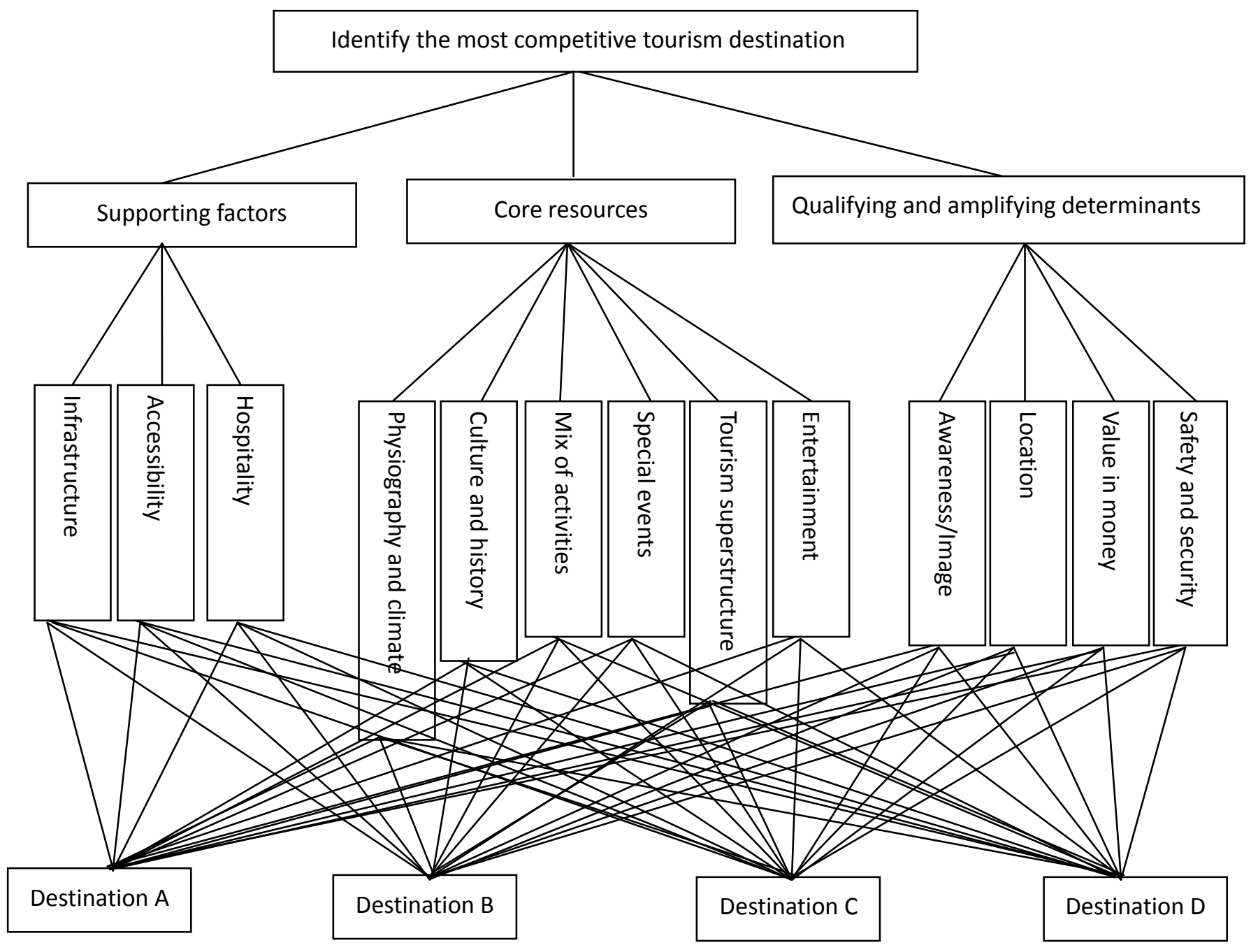

Figure 2. Literature-based AHP Model

The literature-based model is a good model based on previous study. But the data collected from visitors' survey did not contain ample attributes to adopt this model. When the attributes (Table 1) in the survey from the first stage of data collection were applied to the literature-based model (Figure 2), there were two main problems. First, some attributes were forced under certain factors that they did not necessary belong to. For example, well-known landmarks seemed fine as an indicator for awareness/image (Table 5), but in fact, it was 
inappropriate for the following reason. Destination image is believed to be formed and shaped by both organic image and induced image (Echtner \& Ritchie, 1991). The former is the perceived image based on the information visitors obtain from non-tourists, non-commercial sources (e.g., magazines, books, and movies) while the latter is shaped by more commercial sources such as travel brochures about the destination. Put simply, destination image is an overall impression of a destination. So, it would not be valid to use only one attribute (i.e., well-known landmarks) to measure it. Second, some of the factors only had one attribute as an indicator (Table 5). For instance, the category of special events could be measured with the only item special events. Similarly, variety of activities to do was the only attribute under entertainment, and hospitality and friendliness of residents was the only attribute under hospitality. This was not suitable, because, statistically, more criteria for a factor would mean a more reliable and robust measurement for that factor (Kao et al., 2008). Therefore, this study needed to identify an alternative model that is more proper to evaluate West Virginia's tourism competitiveness. 
Table 5

Allocation of Competitiveness Attributes in Literature-based Model

Geography and climate

Good weather/climate

Accessibility of destination

Road condition

\section{Superstructure}

Dedicated tourism attractions

Well-marked roads/attractions

Shopping facilities

Special events \& entertainment

Special events

Hospitality

Hospitality \& friendliness of residents

Qualifying and amplifying factors

Conveniently located

Safety and security

Value for money in shopping items

Value for money in tourism experiences

\section{Culture and history}

Historic site

Interesting architecture

\section{Mix of activities}

Availability of activities for children

Availability of adventure-based

activities

Nature-based activities

\section{Entertainment}

Variety of activities to do

\section{Awareness/image}

Well-known landmarks

\author{
Infrastructure \\ Local transportation efficiency \\ Variety \& quality of \\ accommodation \\ Variety \& quality of restaurants \\ Communication facilities
}

\section{Accessibility}

Visitor accessibility to attractions

Availability of tourist information

\section{Data-driven Model}

Because the data collected from visitors did not fit the literature-based model well, this study proceeded to identifying a data-driven model. This is the model derived from the factor analysis of the tourism attributes in the tourists' surveys (Table 1). The Kaiser-Meyer-Olkin (KMO) measure of sampling adequacy (0.920) and the Barrtlett's test of sphericity $(\mathrm{p}<.001)$ showed that the data was suitable for factor analysis (Table 6). Based on the criterion of Eigenvalue greater than 1.00, four factors were identified from the analysis 
(Table 6) and were named: supporting factors and facilities, core resources, attractions and their accessibility, and qualifying and amplifying determinants, respectively. Twenty-five out of the 26 attributes were grouped under the four factors. Visitor accessibility to attraction was the measurement excluded from the factor analysis based on its factor loading. It loaded as $.459, .451, .355$, and .389 on factor 1 , factor 2 , factor 3 , and factor 4 , respectively. The overall variance explained by the four factors was $68.81 \%$. The reliability of each group was tested and all the groups had Cronbach's Alpha higher than .70, confirming internal consistency of the factors. With the factor analysis results, a data-driven AHP model (Figure 3) was created for destination competitiveness evaluation of West Virginia. The data-driven model was used in subsequent analysis because it fitted the data well in comparison to the literature-based model. 
Table 6

Competitiveness Determinants and Corresponding Indicators based on Factor Analysis

\begin{tabular}{|c|c|c|c|c|c|}
\hline Factor & $\begin{array}{c}\text { Mean } \\
\text { (out of } 5 \text { ) }\end{array}$ & $\begin{array}{l}\text { Factor } \\
\text { loading }\end{array}$ & Eigenvalue & $\begin{array}{l}\text { Explained } \\
\text { variance }\end{array}$ & $\begin{array}{c}\text { Cronbach } \\
\text { Alpha }\end{array}$ \\
\hline Supporting factors and facilities & & & 3.916 & $15.00 \%$ & .889 \\
\hline Value for money in shopping items & 3.93 & .753 & & & \\
\hline Variety and quality of restaurants & 3.82 & .708 & & & \\
\hline Variety and quality of accommodation & 3.82 & .607 & & & \\
\hline Local transportation efficiency & 3.40 & .602 & & & \\
\hline Communication facilities & 3.77 & .602 & & & \\
\hline Road condition & 4.03 & .572 & & & \\
\hline Shopping facilities & 3.65 & .512 & & & \\
\hline Core resources & & & 2.833 & $11.19 \%$ & .817 \\
\hline Nature-based activities & 4.37 & .736 & & & \\
\hline Value for money in tourism experiences & 4.21 & .692 & & & \\
\hline Availability of adventure-based activities & 4.15 & .691 & & & \\
\hline Good weather/climate & 4.17 & .522 & & & \\
\hline Attractions and accessibility & & & 6.413 & $24.67 \%$ & .926 \\
\hline Well-known landmarks & 3.88 & .791 & & & \\
\hline Dedicated tourism attractions & 3.89 & .752 & & & \\
\hline Special events & 3.67 & .745 & & & \\
\hline Interesting architecture & 3.69 & .741 & & & \\
\hline Historic sites & 4.07 & .724 & & & \\
\hline Availability of activities for children & 3.81 & .626 & & & \\
\hline Conveniently located & 3.80 & .612 & & & \\
\hline Availability of tourist information & 4.18 & .565 & & & \\
\hline Variety of activities to do & 3.99 & .498 & & & \\
\hline Qualifying and amplifying determinants & & & 4.419 & $17.00 \%$ & .866 \\
\hline Hospitality \& friendliness of residents & 4.39 & .773 & & & \\
\hline Safety and security & 4.33 & .754 & & & \\
\hline Cleanliness & 4.18 & .725 & & & \\
\hline Well marked roads/attractions & 4.19 & .705 & & & \\
\hline Accessibility of destination & 3.97 & .668 & & & \\
\hline
\end{tabular}

Note. KMO (Kaiser-Meyer-Olkin Measure of Sampling Adequacy) = .920, Bartletts' Test of Sphericity: $\mathrm{P}<.001$ 


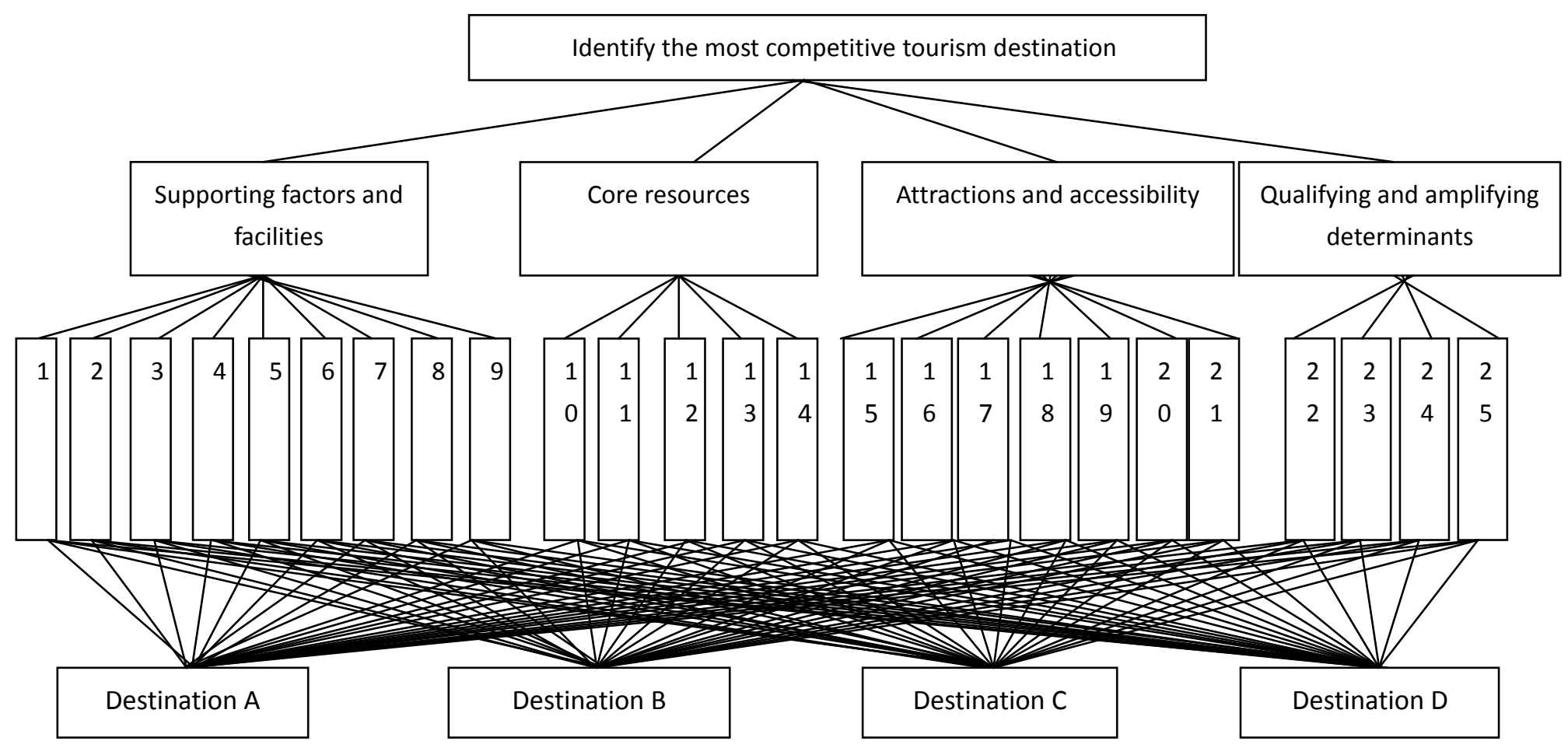

Note: This study used a hybrid method in the AHP: use pairwise comparison to get weights for the factors and attributes at the first and second layers. At the bottom, each destination's overall performance is calculated by multiplying AHP weights by visitors' rating scores.

1: Well-known landmarks, 2:Dedicated tourism attractions,3:Special events 4: Interesting Architecture,5: Historic sites,6: Availability of activities for children, 7:Conveniently located, 8: Availability of tourist information, 9: Variety of activities to do, 10: Hospitality \& friendliness of residents, 11: Safety and security, 12: Cleanliness, 13: Well marked roads/attractions, 14: Accessibility of destination,15: Value for money in shopping items, 16: Variety and quality of restaurants, 17: Variety and quality

Figure 3. Data-driven AHP Model

\section{What are the most and least important tourism attributes for West Virginia's tourism competitiveness?}

The AHP analysis revealed that all the inconsistency ratios (CRs) for CVB directors'

judgment were smaller than 0.10 , indicating very good consistency among the experts'

ratings about relative importance of attributes.

For the four main factors, qualifying and amplifying determinants gained the most weight (.465), followed by attractions and accessibility (.293), core resources (.157), and supporting factors and facilities (.139) in that order (Figure 4). The judgment inconsistent ratio (CR) on the four factors was 0.04 indicating a high consistency among CVB directors' 
collaborative determination about the factors relative importance.

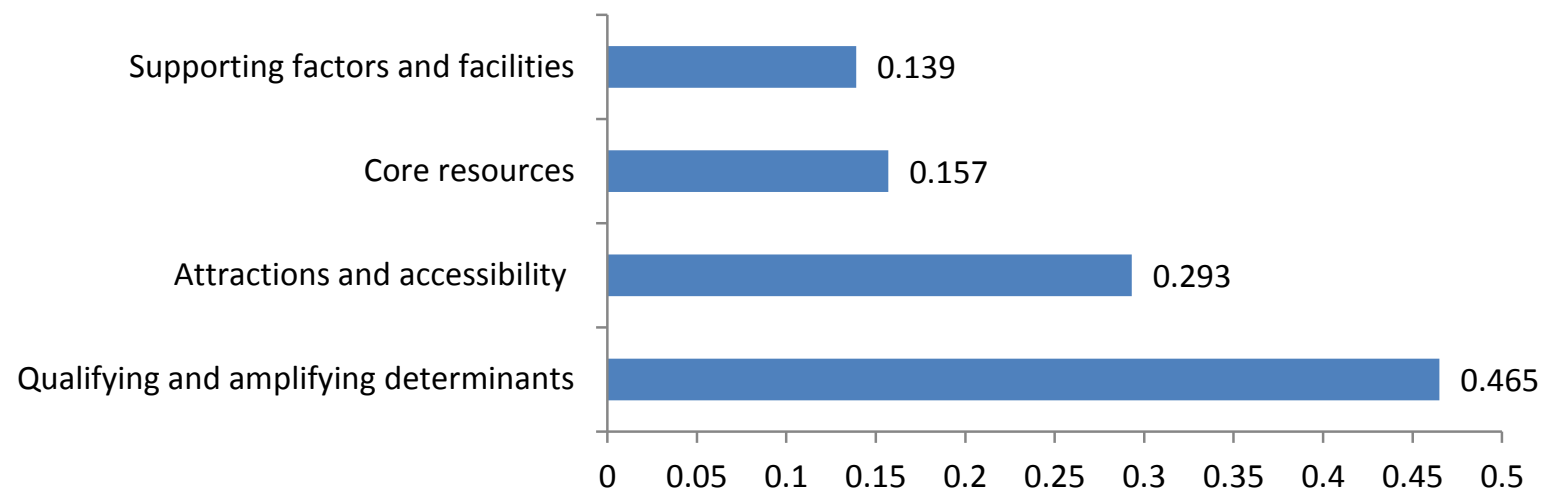

Figure 4. Main Factor Weights

Within supporting factors and facilities (Figure 5), variety and quality of accommodation (.258), variety and quality of restaurants (.228), and shopping facilities (.204) were the three top ranked attributes, meanwhile, local transportation efficiency (.045), road condition (.068), value for money in shopping items (.086), and communication facilities (.112) gained relatively lower weights. The CR (0.07) in this group judgment was quite low, too.

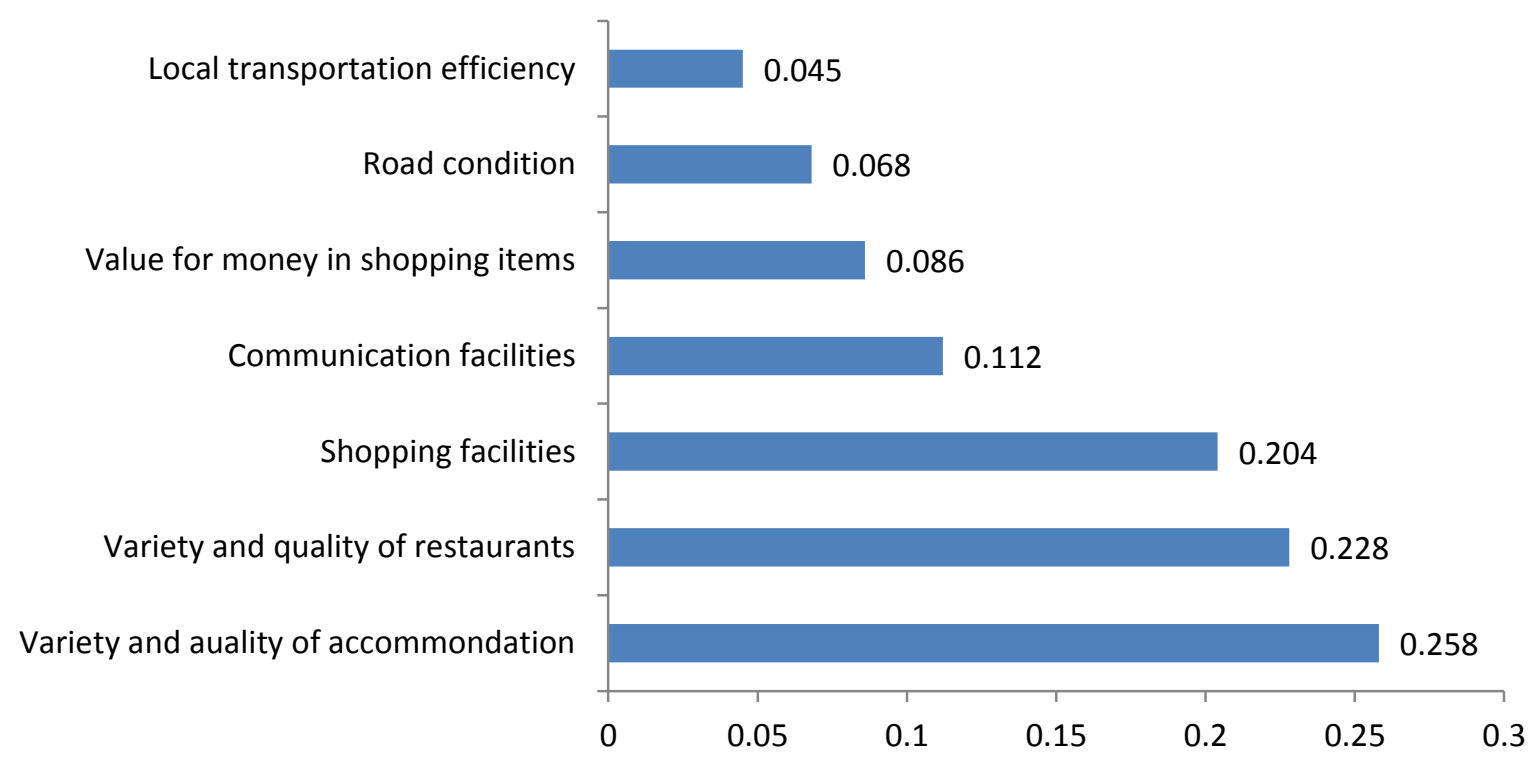

Figure 5. Local Weights of Supporting Factors and Facilities

In terms of core resources (Figure 6), good weather/climate was weighted the most 
(.578). Comparatively, availability of adventure-based activities had much lower weight

(.214), so did value for money in tourism experience (.105) and nature-based activities (.103).

The CR (0.04) for the judgments among the four attributes indicated very good consistency.

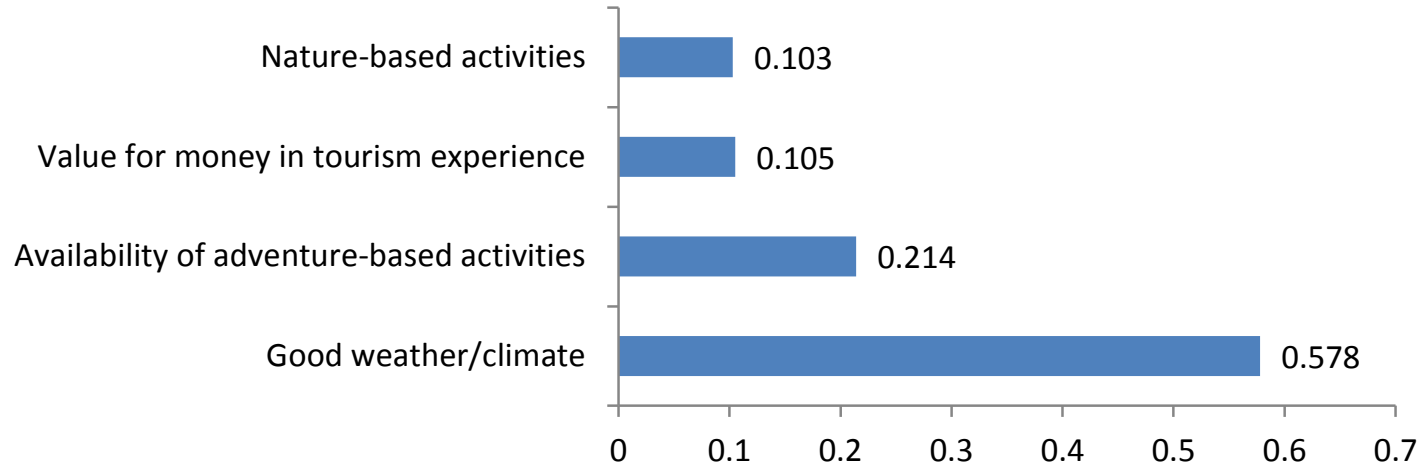

Figure 6. Local Weights of Core Resources

With regard to attractions and accessibility (Figure 7), variety of activities to do was allocated the highest weight (.282). The remaining attributes under this factor could be divided into two groups using .10 as the benchmark. The group with elements weighting more than .10 included conveniently located (.156), availability of activities for children (.145), and availability of information (.130). The other group including special events (.08), historic site (.08), dedicated tourism attractions (.052), interesting architecture (.049), and well-known landmarks (.026). The judgment about these attributes' relative importance was fairly consistent among the attributes with CR (0.08) smaller than 0.10 . 


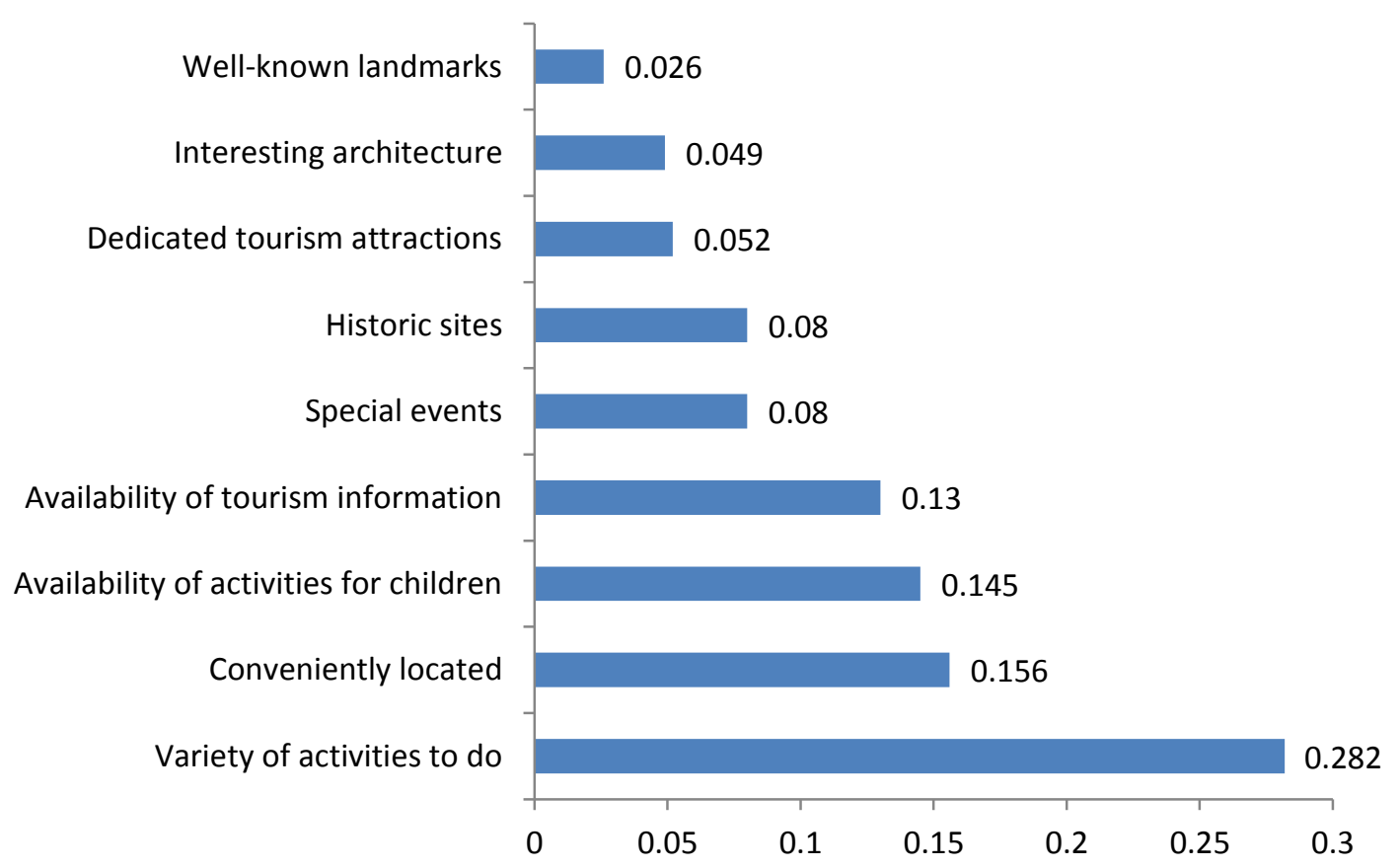

Figure 7. Local Weights of Attractions and Accessibility

With respect to qualifying and amplifying determinants (Figure 8), highest ranked were well-marked roads/attractions (.252), cleanliness (.233), and accessibility of destination (.233). Hospitality and friendliness of residents (.19) was weighted lower than the three elements but higher than safety and security (.092). The value of CR (0.02) indicated very consistent judgment among these attributes. 


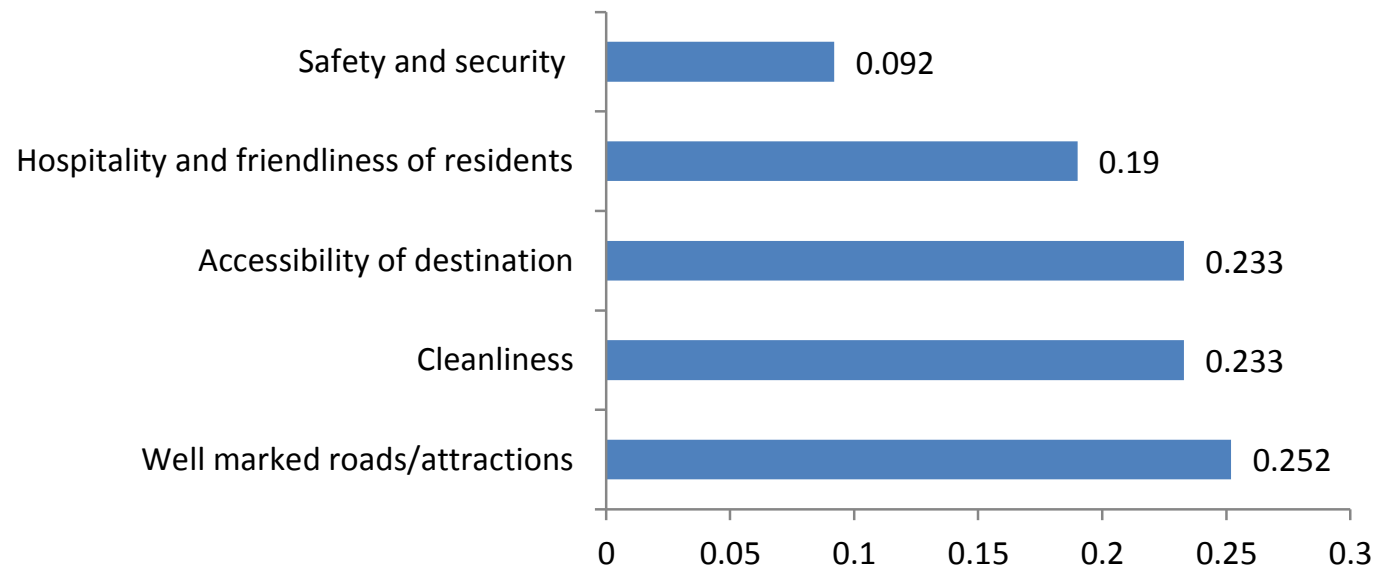

Figure 8. Local Weights of Qualifying and Amplifying Determinants

The global weights (Figure 9) revealed that well-marked roads/attractions (.133), cleanliness (.123), accessibility of destination (.123), and hospitality and friendliness of residents (.1) were highly weighted. The attributes weighting low included well-known landmarks (.006), local transportation efficiency (.007), and value for money in tourism experience (.008), and nature-based activities (.01). The remaining attributes' weights ranged from 0.01 to 0.068 (See Figure 9 for details). The overall CR (0.05) for judgment across all the attributes indicated very good consistency. 


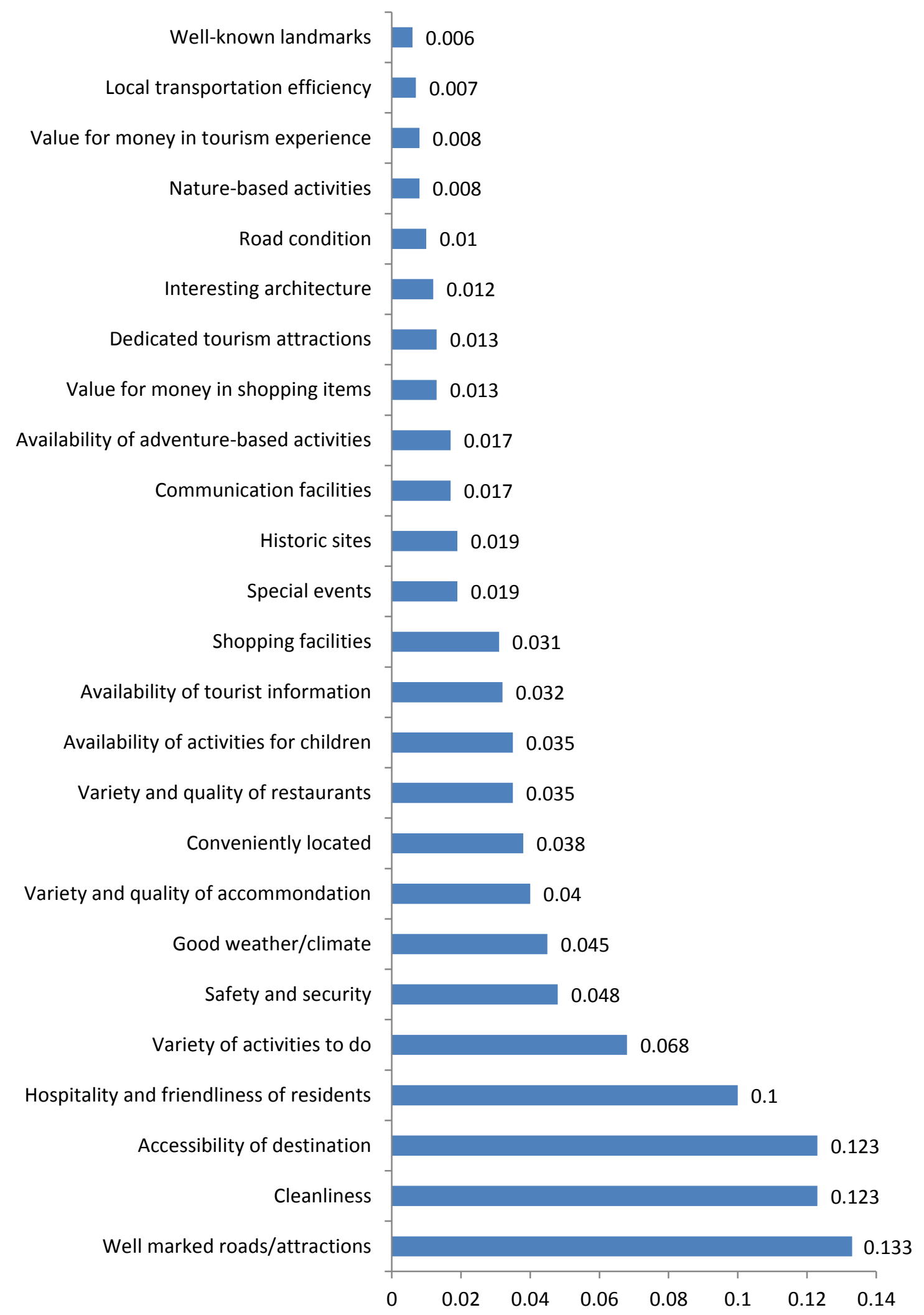

Figure 9. Global Weights of all Competitiveness Attributes

When comparing CVB directors inputs on attribute weights and tourists' ratings of 
West Virginia's performance on the attributes, interesting findings were noted (Table 7). While accessibility of destination, variety of activities to do, and variety and quality of restaurants and accommodations were considered as very important attributes for West Virginia's tourism competitiveness, visitors' rating scores for the state's performance on these attributes were rather low. Although the CVB directors did not give high weights to nature-based activities and value for money in tourism experience, visitors assigned very high performance scores on the two aspects. The attributes that were both allocated with high weights and gave high performance scores included: hospitality and friendliness of residents, safety and security, cleanliness, and well-marked roads/attractions. 
Table 7

Tourism Attributes Weights and West Virginia's Performance on the Attributes

\begin{tabular}{|c|c|c|c|c|}
\hline \multirow[b]{2}{*}{ Factor } & \multicolumn{2}{|c|}{ Performance } & \multicolumn{2}{|c|}{ Importance } \\
\hline & $\begin{array}{c}\text { Mean } \\
\text { (out of } 5 \text { ) }\end{array}$ & Rank & $\begin{array}{l}\text { Weights } \\
\text { (out of } 1 \text { ) }\end{array}$ & Rank \\
\hline \multicolumn{5}{|l|}{ Supporting factors and facilities } \\
\hline Value for money in shopping items & 3.93 & 14 & 0.013 & 14 \\
\hline Variety and quality of restaurants & 3.82 & 17 & 0.035 & 9 \\
\hline Variety and quality of accommodation & 3.82 & 17 & 0.040 & 7 \\
\hline Local transportation efficiency & 3.40 & 23 & 0.007 & 18 \\
\hline Communication facilities & 3.77 & 20 & 0.017 & 13 \\
\hline Road condition & 4.03 & 10 & 0.010 & 16 \\
\hline Shopping facilities & 3.65 & 11 & 0.031 & 11 \\
\hline \multicolumn{5}{|l|}{ Core resources } \\
\hline Nature-based activities & 4.37 & 2 & 0.008 & 17 \\
\hline Value for money in tourism experiences & 4.21 & 4 & 0.008 & 17 \\
\hline Availability of adventure-based activities & 4.15 & 8 & 0.017 & 13 \\
\hline Good weather/climate & 4.17 & 7 & 0.045 & 6 \\
\hline \multicolumn{5}{|l|}{ Attractions and accessibility } \\
\hline Well-known landmarks & 3.88 & 16 & 0.006 & 18 \\
\hline Dedicated tourism attractions & 3.89 & 15 & 0.013 & 11 \\
\hline Special events & 3.67 & 22 & 0.019 & 12 \\
\hline Interesting architecture & 3.69 & 21 & 0.012 & 15 \\
\hline Historic sites & 4.07 & 9 & 0.019 & 12 \\
\hline Availability of activities for children & 3.81 & 18 & 0.035 & 9 \\
\hline Conveniently located & 3.80 & 19 & 0.038 & 8 \\
\hline Availability of tourist information & 4.18 & 6 & 0.032 & 10 \\
\hline Variety of activities to do & 3.99 & 13 & 0.068 & 4 \\
\hline \multicolumn{5}{|l|}{ Qualifying and amplifying determinants } \\
\hline Hospitality \& friendliness of residents & 4.39 & 1 & 0.100 & 3 \\
\hline Safety and security & 4.33 & 3 & 0.048 & 5 \\
\hline Cleanliness & 4.18 & 6 & 0.123 & 2 \\
\hline Well marked roads/attractions & 4.19 & 5 & 0.133 & 1 \\
\hline Accessibility of destination & 3.97 & 11 & 0.123 & 2 \\
\hline
\end{tabular}

What are the strengths and weaknesses of West Virginia as a tourism destination compared to neighboring competitors?

Virginia, Maryland, and Pennsylvania were identified as the top three competing tourism destinations for West Virginia based on the other mostly visited destinations by the tourists to the state (Table 8). The current study used the three states as West Virginia's potential neighboring competitors. The four states are all located in the east part of United 
States, but Virginia, Maryland, and Pennsylvania belong to the Mid-Atlantic States where large cities with mass populations are located.

\section{Table 8}

Other Recently Visited Eastern States by Respondents ( $\mathrm{N}=275)$

\begin{tabular}{|c|c|c|c|}
\hline State & Frequency & State & Frequency \\
\hline Virginia & 55 & New Jersey & 7 \\
\hline Maryland & 55 & Delaware & 5 \\
\hline Pennsylvania & 42 & Tennessee & 5 \\
\hline New York & 29 & South Carolina & 4 \\
\hline Florida & 16 & Ohio & 3 \\
\hline North Carolina & 14 & Vermont & 2 \\
\hline Washington DC & 14 & Alabama & 2 \\
\hline Massachusetts & 10 & Georgia & 2 \\
\hline Maine & 8 & New Hampshire & 2 \\
\hline
\end{tabular}

All of the four destinations had good weighted scores for their performances on the attributes of weather/climate, variety of activities to do, variety and quality of accommodations, and well-marked roads/attraction (Table 9). Relatively, all States' performances on road condition, dedicated tourism attraction, interesting architectures, local transportation efficiency, and well-known landmarks were quite low (Table 9), indicating that these attributes did not strongly contribute to the destinations' competitiveness. Results (Table 9) also indicated that West Virginia had higher scores than Virginia, Maryland, and Pennsylvania in terms of availability of adventure-based activities, hospitality and friendliness of residents, availability of tourism information, nature-based activities, safety 
and security, and value for money in shopping items. The weaknesses of West Virginia lied in the areas including accessibility of destination, variety and quality of restaurants, and availability of activities for children. 
Table 9

Four Destinations' Weighted Performance Scores on Specific Attributes

\begin{tabular}{|c|c|c|c|c|c|c|c|c|}
\hline \multirow[t]{2}{*}{ Attributes } & \multicolumn{8}{|c|}{ Destination Performance \& Rank } \\
\hline & WV & Rank & VA & Rank & MD & Rank & PA & Rank \\
\hline Good weather/climate. & 2.30 & 1 & 2.50 & 1 & 2.19 & 1 & 2.17 & 1 \\
\hline Variety of activities to do & 1.13 & 2 & 1.22 & 2 & 1.13 & 2 & 1.12 & 2 \\
\hline Well-marked roads/attractions & 1.07 & 3 & 1.09 & 4 & 1.00 & 4 & 0.97 & 4 \\
\hline Variety and quality of accommodation & 1.04 & 4 & 1.11 & 3 & 1.05 & 3 & 1.00 & 3 \\
\hline Cleanliness & 1.00 & 5 & 0.98 & 7 & 0.87 & 7 & 0.87 & 6 \\
\hline Availability of adventure-based activities & 0.90 & 6 & 0.85 & 9 & 0.79 & 9 & 0.74 & 9 \\
\hline Accessibility of destination & 0.89 & 7 & 1.00 & 5 & 0.90 & 6 & 0.96 & 5 \\
\hline Variety and quality of restaurants & 0.87 & 8 & 0.98 & 6 & 0.93 & 5 & 0.85 & 7 \\
\hline Hospitality \& friendliness of residents & 0.83 & 9 & 0.79 & 10 & 0.73 & 10 & 0.73 & 10 \\
\hline Shopping facilities & 0.73 & 10 & 0.85 & 8 & 0.81 & 8 & 0.85 & 8 \\
\hline Conveniently located & 0.61 & 11 & 0.66 & 11 & 0.63 & 11 & 0.57 & 11 \\
\hline Availability of tourism information & 0.56 & 12 & 0.55 & 13 & 0.52 & 13 & 0.48 & 13 \\
\hline Availability of activities for children & 0.55 & 13 & 0.60 & 12 & 0.55 & 12 & 0.55 & 12 \\
\hline Nature-based activities & 0.45 & 14 & 0.39 & 16 & 0.37 & 16 & 0.35 & 16 \\
\hline Value for money in tourism experience & 0.44 & 15 & 0.43 & 15 & 0.37 & 15 & 0.37 & 15 \\
\hline Communication facilities & 0.43 & 16 & 0.46 & 14 & 0.44 & 14 & 0.40 & 14 \\
\hline Safety and security & 0.40 & 17 & 0.37 & 17 & 0.34 & 17 & 0.33 & 17 \\
\hline Value for money in shopping items & 0.34 & 18 & 0.33 & 19 & 0.32 & 20 & 0.30 & 19 \\
\hline Historical sites & 0.33 & 19 & 0.35 & 18 & 0.32 & 19 & 0.31 & 18 \\
\hline Special events & 0.30 & 20 & 0.32 & 20 & 0.32 & 18 & 0.30 & 20 \\
\hline Road conditions & 0.27 & 21 & 0.28 & 21 & 0.26 & 21 & 0.24 & 21 \\
\hline Dedicated tourism attraction & 0.20 & 22 & 0.23 & 22 & 0.22 & 22 & 0.21 & 22 \\
\hline Interesting architecture & 0.18 & 23 & 0.19 & 23 & 0.20 & 23 & 0.18 & 23 \\
\hline Local transportation efficiency & 0.15 & 24 & 0.18 & 24 & 0.18 & 24 & 0.16 & 24 \\
\hline Well-known landmarks & 0.10 & 25 & 0.11 & 25 & 0.11 & 25 & 0.09 & 25 \\
\hline
\end{tabular}

Note. The weighted scores of destinations' performance on each attribute was calculated by multiplying an attribute's weight by its rating score assigned by tourists. WV: West Virginia, VA: Virginia, MD: Maryland, PA: Pennsylvania.

Virginia performed the best on the four main factors influencing destination competitiveness (Table 10). With respect to supporting factors and facilities, and attraction and corresponding facilities, Maryland's performance ranked the second, followed by West Virginia's and Pennsylvania's (Table 10). In terms of core resources, West Virginia ranked second, followed by Maryland and Pennsylvania in that order (Table 10). West Virginia ranked second on the factor of qualifying and amplifying determinants, where Pennsylvania 
ranked third and Maryland forth (Table 10).

Table 10

Four Destinations' Weighted Performance Scores on Main Factors

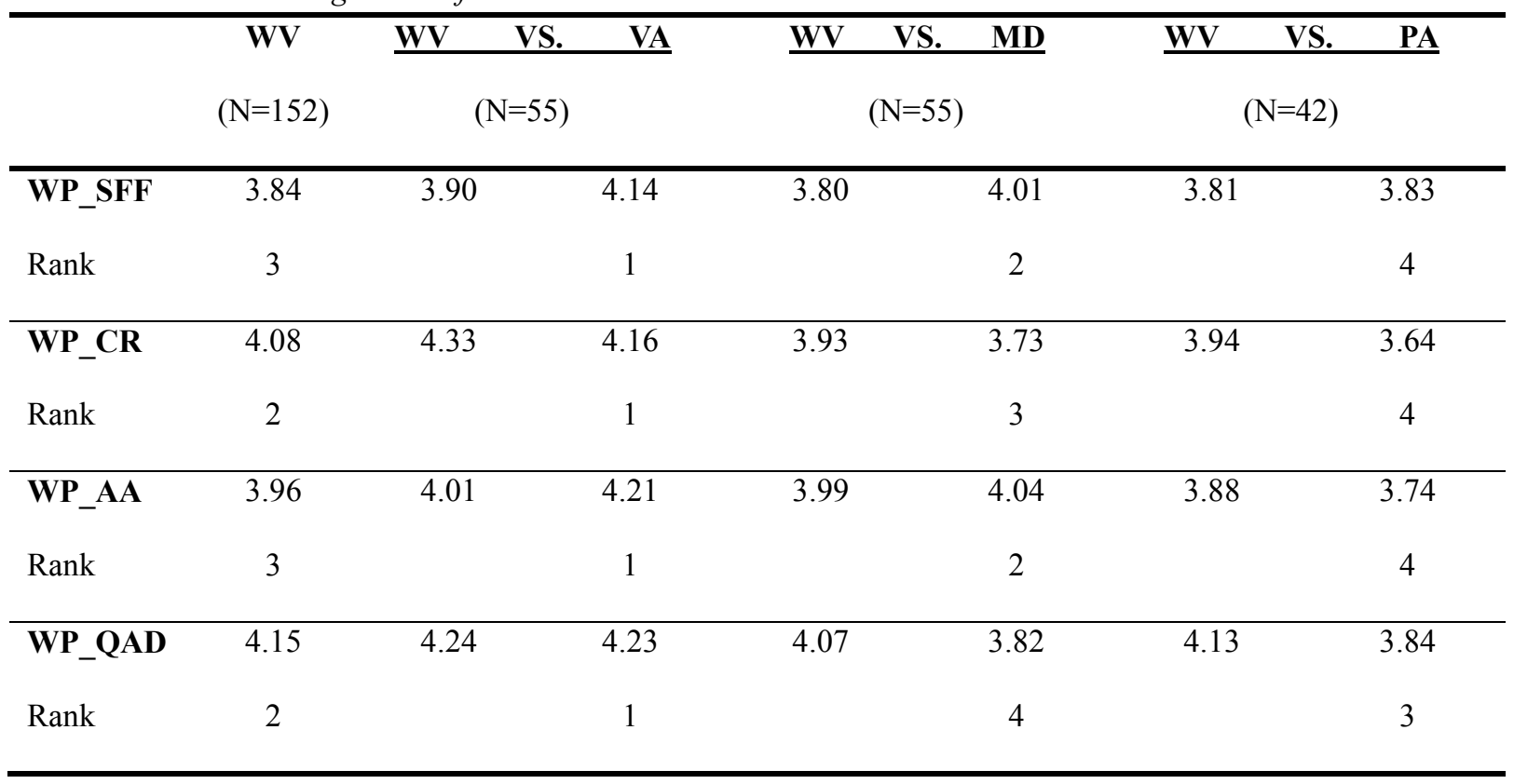

Note: WP_SFF: weighted performance of supporting factors and facilities, WP_CR: weighted performance of core resources; WP_AA: weighted performance of attractions and accessibility; WP_QAD: weighted performance of qualifying and amplifying determinants; WV: West Virginia; VA: Virginia; MD: Maryland; PA: Pennsylvania.

\section{What is West Virginia's overall competitive position in relation to its neighboring competitors?}

Factor weights and attribute weights were applied in the AHP. Four destinations' overall tourism performances were calculated (Figure 10). With a score of 4.37 out of 5.00, Pennsylvania was the most competitive one among the four destinations. West Virginia (4.22) was less competitive than Virginia but better than both Maryland (4.08) and Pennsylvania (3.96). Non-weighted performances were also examined to see if the performance ranks change. Results depicted that the non-weighted performance scores were all lower than weighted performance (Table 11), but this did not change the four destinations' performance ranks. 


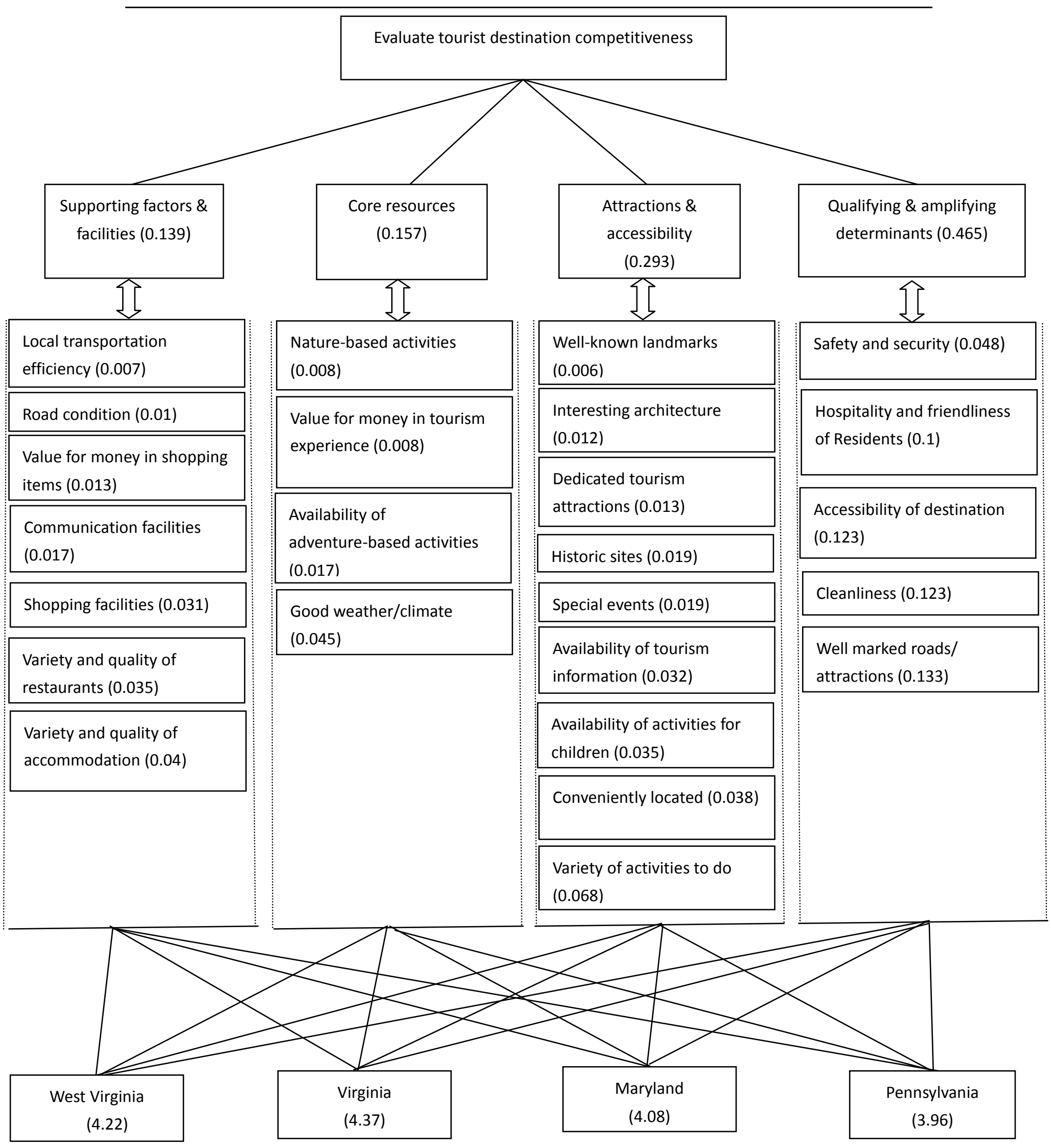

Note: The weights in each layer of the hierarchy should total to one. They do not sum up to one due to rounding. The numbers at the bottom layer denotes the performance score of each destination.

Figure 10. Final Model of Destination Competitiveness Evaluation 
Table 11

Four Destinations' Overall Weighted and Non-weighted Performance Scores (out of 5)

\begin{tabular}{|c|c|c|c|c|c|c|c|c|}
\hline & $\mathbf{W V}$ & $\underline{\mathbf{W V}}$ & $\begin{array}{ll}\text { V.S } & \text { VA } \\
\end{array}$ & WV & V.S $\quad$ MD & $\underline{\text { WV }}$ & V.S & $\mathbf{P A}$ \\
\hline Performance & $(\mathrm{N}=152)$ & \multicolumn{2}{|r|}{$(\mathrm{N}=55)$} & \multicolumn{2}{|c|}{$(\mathrm{N}=55)$} & \multicolumn{3}{|c|}{$(\mathrm{N}=42)$} \\
\hline Weighted & 4.22 & 4.34 & 4.37 & 4.17 & 4.08 & 4.14 & & 3.96 \\
\hline Rank & 2 & & 1 & & 3 & & & 4 \\
\hline Non-weighted & 4.02 & 4.09 & 4.12 & 3.99 & 3.89 & 3.99 & & 3.72 \\
\hline Rank & 2 & & 1 & & 3 & & & 4 \\
\hline
\end{tabular}

Note. WV: West Virginia, VA: Virginia, MD: Maryland, PA: Pennsylvania.

\section{Does the AHP method make a significant difference in destination competitiveness evaluation compared to the non-weighted method?}

The null hypothesis: there is no significant difference in evaluation results between AHP and non-weight method, was tested on five factors (Table 11).

Results (Table 12) showed that West Virginia's weighted performance on supporting factors and facilities $(M=3.8255, S D=0.7401)$ was significantly higher than its non-weighted performance $(M=3.7999, S D=0.7389)$ on this factor, $t(201)=2.819, p<.01$. But the State's weighted performance score on core resources $(M=4.0991, S D=0.6896)$ was significantly lower than the non-weighted performance score $(M=4.2459, S D=0.6614), t$ $(183)=-3.756, p<.001$. Its weighted performance score on attractions and accessibility $(M=$ 3.8667, $S D=0.7405)$ was also significantly lower than the non-weighted score $(M=4.0984$, $S D=0.6914), t(156)=-3.471, p<.01$, and weighted score on qualifying and amplifying determinants $(M=4.1663, S D=0.6143)$ significantly lower than the non-weighted score $(M$ $=4.1927, S D=0.6080)$ as well, $t(244)=-5.804, p<.001$. The State's weighted overall performance $(M=4.1784, S D=0.6428)$ was significantly higher than its non-weighted performance $(M=3.2119, S D=0.4444), t(142)=-34.728, p<.001$. Therefore, the null hypothesis was rejected, indicating that AHP does make a significant difference in destination 
competitiveness evaluation in comparison to the non-weighted method.

Table 12

Comparison between Weighted Performance and Non-weighted Performance

\begin{tabular}{lcccc}
\hline \multicolumn{1}{c}{ Factors } & Means & Std & & \\
& (Weighted - Non-weighted) & deviation & t & df \\
\hline Supporting factors and facilities & $.0257^{* *}$ & .1294 & 2.819 & 201 \\
Core resources & $-.1468^{* * *}$ & .5302 & -3.756 & 183 \\
Attractions and accessibility & $-.2318^{* * *}$ & .8366 & -3.471 & 156 \\
Qualifying and amplifying determinants & $-.0263^{* * *}$ & .0710 & -5.804 & 244 \\
Overall performance & $.9665^{* * *}$ & .3328 & 34.728 & 142 \\
\hline
\end{tabular}

Note. $* * P<0.01, * * * P<0.001$. 


\section{Chapter 5. Discussion and Conclusions}

This chapter comprises of main sections. First, significant findings are discussed.

Second, conclusions are made, in which managerial and theoretical implications and future research are presented.

\section{Discussion}

In this study, core resources and attractions were assigned higher weights than supporting factors and facilities but lower than the factor of qualifying and amplifying determinants. This was an interesting finding. In past research, scholars found that core resources and attraction are the fundamental reasons tourists choose one destination over another (Ritchie \& Crouch, 2003). According to the literature, core resources and attractions should be the most important competitiveness attributes with the highest weights. In contrast, from the perspectives of the experts in West Virginia, the most important factor was qualifying and amplifying determinants including security, hospitality and friendliness of residents, accessibility of destination, cleanliness, and well-marked roads/attractions. This might be due to the fact that while core resources and attractions are the core of a tourism destination, they cannot be fully used to attract tourists unless other factors that facilitate the development of them are good (e.g., hospitality and friendliness of residents) or well-designed (e.g., well-marked roads/attractions). This finding actually also corresponded to Ritchie and Crouch's (2003) study, in which they stated that the qualifying and amplifying determinants do make or break a destination's competitiveness regardless of how well the destination does in other factors.

Under the factor of attractions and accessibility, the attributes of variety of activities to do, conveniently located, and availability of activities for children were allocated the highest 
weights while well-known landmarks, interesting architecture, dedicated tourism attractions, and historic sites had the lowest weights. This may indicate that the directors will place more value on activity planning, design, and implementation. One of the directors the author interviewed gave fairly low weight on well-known landmarks and interesting architecture. When asked why he did this way, he explained that when people are on vacation, they care more about what they could do with their companion instead of the place they go, and therefore, diversity of activities should be given high weights.

The factor of qualifying and amplifying determinants had the highest weight and the attributes under this factor also received comparatively higher weights: all of the top four highly weighted attributes belonged to this main component as presented in Results section. The results indicated that CVB directors perceived high importance of good signage, destination hygiene, ease of access, and residents' friendliness to tourists in terms of these attributes' role in determining West Virginia's tourism competitiveness.

The results of destinations' performance on specific attributes revealed that West Virginia performed well on availability of adventure-based activities, nature-based activities. This was not a surprising finding since the State is marketed and nicknamed Wild and Wonderful West Virginia. The finding that West Virginia had a competitive edge on hospitality and friendliness of residents, safety and security, and value for money in shopping items implied that the State is perceived as a more friendly state where tourists get good value for their money and also do not have to worry much about their safety and security. The good performance of West Virginia on hospitality, and safety and security is consistent with what the CVB directors perceived as the two most important attributes that contribute to the State's 
destination competitiveness.

Destinations' performance on specific factors indicated that Virginia outperformed all the other destinations in every aspect. West Virginia ranked second in terms of core resources, and qualifying and amplifying determinants. Pennsylvania ranked the lowest with regard to three factors expects qualifying and amplifying determinants. Maryland had mediocre ranks in competitiveness factors, but it ranked the lowest on the amplifying and qualifying determinants. The results showed that West Virginia still needs to improve to compete with Virginia on all aspects while its performance was better than the other two potential neighboring competitors (i.e., Maryland, and Pennsylvania).

AHP did not make changes in the ranks of both the four destinations' performance on specific factors (Table 9) and overall performance (Table 10), seemly indicating that this method would not make much difference in evaluation results. However, it was evident that the AHP did result in higher scores of destinations' performance than non-weighted ones. This could imply that without the approach of AHP, evaluators may underestimate (in this case) or overestimate (maybe other cases) the performance of their destinations evaluated.

The utility or effect of AHP was fully revealed as the null hypothesis was rejected that there is no significant difference in destination competitiveness evaluation between AHP and non-weighted method. Results indicated that AHP made a significant difference in the evaluation results. Weights for attributes in the process did make a difference in evaluation result. In the study, weighted performances of three out of the four main factors were significant lower than non-weighted results, but the weighted overall performance was significantly higher than the non-weighted result. Therefore, it could be asserted that without 
allocating weights to attributes in evaluation process, overestimation or underestimation may occur, which can lead to other undesirable management decisions such as misallocation of resources or misprioritization of management actions.

\section{Conclusions}

The objective of this study was triple: First, it aimed to apply the AHP method to determine the relative importance of resource-based tourism attributes determining destination competitiveness. Second, it evaluated West Virginia's competitiveness as a tourism destination compared to its potential neighboring competitors. Last, it sought to investigate if the AHP method makes a significant difference in competitiveness evaluation in comparison to the non-weighted evaluation approach. To achieve the goals, five research questions were proposed and investigated (see Introduction for details). Based on literature review and preliminary factor analysis, an appropriate evaluation model (Figure 3) was constructed and chosen to evaluate West Virginia's tourism competitiveness in relation to three other destinations: Virginia, Maryland, and Pennsylvania. AHP was applied to the evaluation process. Significant findings were noted.

The most important attributes that determine West Virginia's tourism competitiveness were found to be well-marked roads/attractions, cleanliness, accessibility of destination, hospitality and friendliness of residents, variety of activities to do, safety and security, good weather/climate, variety and quality of accommodation. Attributes that are deemed as the least important include well-known landmarks, local transportation efficiency, value for money in tourism experience, nature-based activities, and road condition.

Supporting factors and facilities, core resources, attractions and accessibility, and 
qualifying and amplifying determinants are considered as the four distinct factors that determine West Virginia's destination competitiveness. Within each factor, specific attributes were presented (Table 6). Compared to Virginia, Maryland, and Pennsylvania, West Virginia performed fairly well on the second and the forth factors, but it was less competitive on the first and the third one.

Specifically, West Virginia has competitive edge over its competitors in terms of availability of adventure-based activities, hospitality and friendliness of residents, availability of tourism information, nature-based activities, safety and security, and value for money in shopping items, while it is less competitive in areas such as accessibility of destination, variety and quality of restaurants, and availability of activities for children.

West Virginia ranked second in terms of its overall competitive position, following Virginia but preceding Maryland and Pennsylvania.

The results in this study suggest that AHP makes a significant difference in destination competitiveness evaluation in comparison to non-weighted approach. Without using AHP, evaluators may overestimate or underestimate a destination's tourism performance and thus misjudge its competitive position.

\section{Implications}

The originality of this study is that competiveness evaluation emphasizes on resource-based attributes, and that attributes importance levels are determined by destination management using AHP, destinations' performance on the attributes are evaluated by tourists who actually experience the destinations. The study has two important theoretical contributions. First, this study strengthens the efficacy of AHP in destination competitiveness 
evaluation. While the study does not state that AHP can supersede traditional established evaluation method, it does suggest that AHP helps avoid underestimating or overestimating destination performance and thus is a feasible and reliable tool to evaluate destination competitiveness. Second, it provides new insights into tourism destination competiveness management (Figure 11). The flow chart illustrates a process of managing destination competitiveness. Destination management decides the relative importance of different tourism attributes. Tourists evaluate the destination's performance on these attributes. With AHP, the relative performance of tourism attributes can be calculated and the destination's competitive position in relation to other competing destinations can be revealed. If the destination performs better than its competitors on certain factors/attributes, current management could continue, but if it performs worse comparatively, corresponding adjustments could be made. Since tourism is a dynamic system, everything changes constantly; ongoing monitoring or new research will be needed to keep destination competitive. 
Management Criterion

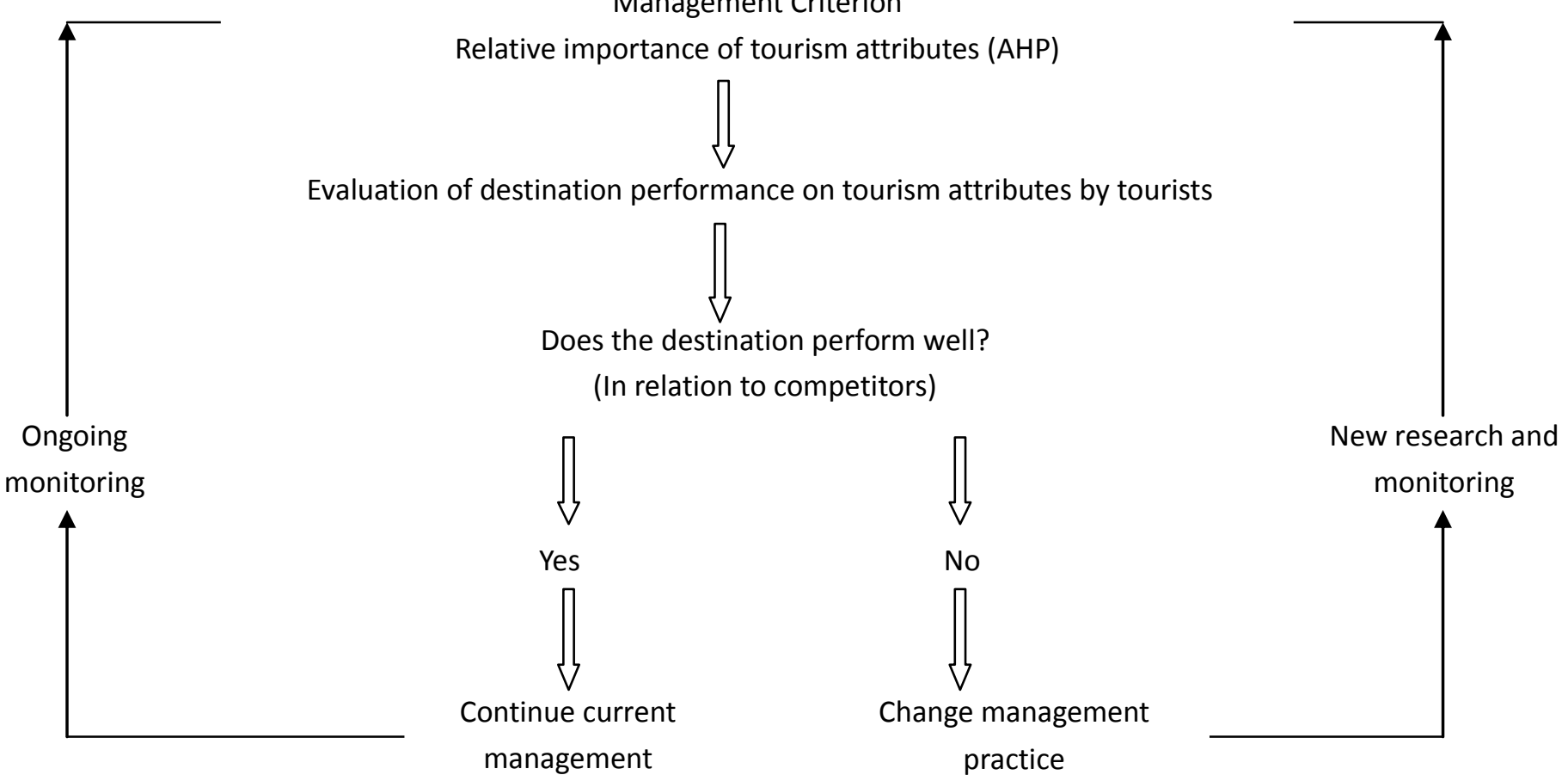

Figure 11. The Flow of Destination Competitiveness Management

Results from this study also suggest several management implications.

The resource-based competitiveness approach assesses a destination's resource strengths and weaknesses compared to its competing destinations. The approach provides destination managers a clear picture of their destination's performances so that they could adjust their current management strategy accordingly to make the most of their resources. For instance, as discussed earlier under the Discussion, West Virginia was found to have a competitive edge over its neighboring competitors with respect to availability of adventure-based activities, nature-based activities, hospitality and friendliness of residents, safety and security, and value for money in shopping items. The States' marketing message should capitalize on these positive aspects and strengths to make the destination more appealing to potential tourists.

Attributes accorded high weights should obtain great attention from management such 
as safety and security, hospitality and friendliness of residents, accessibility of destination, cleanliness, and well-marked roads/attractions. Safety and security, and hospitality and friendliness of residents seemed out of the control of tourism management because it involves more government action and more "buy-in" from residents about tourism development. What destination managers could do is to take residents' interests into consideration and involve them when plans are designed. The accessibility of a destination, to some extent, can be enhanced by providing potential visitors more transportation information and routes packages. Cleanliness of a destination is a collaborative effort of all residents and management. What destination managers can do in their area is to allocate necessary budget and personnel to ensure a hygienic environment for their visitors.

Paying attention to attributes that gain higher weights does not mean that attributes with lower weights could be neglected for two main reasons. First, every aspect should be well managed because small problems in many minor aspects could grow into big issues. For instance, value for money in tourism experience did not have a high weight, but if tourists perceive low utility for their spending, they could end up being unsatisfied and spread negative word-of-mouth about spending in the destination. Nature-based activities gained low weight in this study. This might due to the factor that the State does really well on these so that CVB directors might be taking this for granted or thinking that the State's effort should focus on exploring other areas. If management neglect this aspect and lack necessary support for nature-based activity development, the State may go astray from its Wild and Wonderful image and lose their base and potential customers. Second, it should be noted that local weights are influenced by the number of attributes within a factor and global weights by both 
the number of attributes and factors included in the hierarchy. So when the counts of attributes under factors are not equal, global weights will be less convincing. For instance, there were nine attributes under attraction and accessibility, and if only four attributes (e.g., historic sites, special events, dedicated attractions, and availability of activities for children) included in this factor, the local weights for the four attributes will be bigger, and so will their global weights. This phenomenon could be boiled down to the fact that all the local weights within a factor should be accumulated to one. So, the less the number of attributes are, the higher the local weights are. Similarly, if only three factors involved in this evaluation, their corresponding weights will become bigger than there were four. The global weights of all attributes should be accumulated to one. More attributes in the evaluation process means lower weights for attributes than there are less attributes. Therefore, when there are many factors and attributes involved in an evaluation process, it is less meaningful to look at the decimal numbers that represent the weights. It will be more practical to look at their weight ranks to see the relative importance.

While this study assessed different destinations' weighted performance on each factor and gave corresponding ranks, caution should be used when destination managers interpret the findings. In this study, the factors were named subjectively. Different people may bestow different names upon the four factors. Managers should examine the specific attributes within a factor to gain a better understanding of what the findings accurately point to if they are to use the findings to direct their management decisions. 


\section{Future research}

Despite the important contributions it makes, the study is not without limitations. To address the limitations, possible future research is suggested.

In this study, potential neighboring destination competitors were identified from tourists who listed an eastern US destination they had recently visited, but competitors should include those who compete for the same potential markets. Strictly speaking, West Virginia's competitors should be destinations which tourists give up in order to choose West Virginia as their destination. Virginia, Maryland and Pennsylvania are neighboring states of West Virginia, but they do not necessarily compete with each other in the tourism market. Further research should compare destinations based on actual competing destinations for specific target market.

This study used CVB directors to determine tourism attributes' relative importance and tourists to evaluate destinations' performance on the attributes. In this study, the common destination the tourists knew was West Virginia. Tourists who rated Virginia did not necessarily assess Maryland and Pennsylvania. Likewise, tourists who evaluated Maryland or Pennsylvania did not necessarily provide their insights into the other two destinations. It is likely that evaluation results will be somewhat different if all the tourists were to rate every destination in this study. In the future, studies could try to include evaluators familiar with all the destinations evaluated so that their ratings are more comparable.

The study points out that using tourists to derive weights is not practical because the AHP survey instrument is lengthy. This is not meant to discourage research from using tourists to derive weights. Using tourists in both weighting and rating processes can be 
rewarding for it provides a way to identify the gap between visitors' expectation and destinations' performance on tourism attributes.

The current study utilized only a priori weights. Future study can address both a priori weights (derived from expert survey) and a posteriori weights (derived from visitor survey), and examine if there are significant differences in the perception of relative importance of tourism attributes between experts and visitors. Or, future research could invite visitor to derive both a priori and a posteriori weights, which will generate an understanding of destination competitiveness evaluation with different methods.

The data collection from visitors was conducted in summer. Visitors in different season may have different opinions about the destinations' performance. Future research could conduct data collection in winter or throughout the year, and examine if there are significant differences in destinations' competitiveness in different time period during a year. 


\section{References}

Alphonce, C. B. (1997). Application of the analytic hierarchy process in agriculture in developing countries. Agricultural systems, 53(1), 97-112.

Ambastha, A., \& Momaya, K. (2004). Competitiveness of firms: review of theory, frameworks, and models. Singapore Management Review, 26(1), 45-61.

Azzoni, C. R., \& de Menezes, T. A. (2009). Cost competitiveness of international destinations. Annals of Tourism Research, 36(4), 719-722.

Banai-Kashani, R. (1989). A new method for site suitability analysis: The analytic hierarchy process. Environmental Management, 13(6), 685-693.

Barney, J. (1991). Firm resources and sustained competitive advantage. Journal of management, 17(1), 99-120.

Beirman, D. (2003). Restoring tourism destinations in crisis: A strategic marketing approach [online]. In: Braithwaite, Robyn L (Editor); Braithwaite, Richard W (Editor). CAUTHE 2003: Riding the Wave of Tourism and Hospitality Research. Lismore, N.S.W.: Southern Cross University

Bunruamkaew, K. (March 1 ${ }^{\text {st }}$, 2012). How to do AHP analysis in Excel. Division of Spatial Information Science, Graduate School of Life and Environmental Sciences, Universtiy of Tsukuba.

Chiang, C. M., \& Lai, C. M. (2002). A study on the comprehensive indicator of indoor environment assessment for occupants' health in Taiwan. Building and Environment, 37(4), 387-392.

Chen, C. F. (2006). Applying the analytical hierarchy process (AHP) approach to convention site selection. Journal of Travel Research, 45(2), 167-174.

Chon, K. S., \& Mayer, K. J. (1995). Destination competitiveness models in tourism and their application to Las Vegas. Journal of Tourism Systems and Quality Management, 1(2), 3. 
Chou, T. Y., Hsu, C. L., \& Chen, M. C. (2008). A fuzzy multi-criteria decision model for international tourist hotels location selection. International journal of hospitality management, 27(2), 293-301.

Cracolici, M. F., \& Nijkamp, P. (2009). The attractiveness and competitiveness of tourist destinations: A study of Southern Italian regions. Tourism Management, 30(3), 336-344.

Crouch, G. I. (2011). Destination competitiveness: an analysis of determinant attributes. Journal of Travel Research, 50(1), 27-45.

Crouch, G. I., \& Ritchie, J. R. (1999). Tourism, competitiveness, and societal prosperity. Journal of business research, 44(3), 137-152.

Crouch, G. I., \& Ritchie, J. B. (2000). The competitive destination: a sustainability perspective. Tourism management, 21(1), 1-7.

Czaja, S. J., Schulz, R., Lee, C. C., \& Belle, S. H. (2003). A methodology for describing and decomposing complex psychosocial and behavioral interventions. Psychology and aging, 18(3), 385.

Dean Runyan Associates. (2013). Economic impact of travel on West Virginia: 2000-2012 detailed state and county estimates. Retrieved April 7, 2014 from http://www.wvcommerce.org/App_Media/assets/doc/travelandrec/industry/marketing/2010\%20Econo mic\%20Impact.pdf

De Keyser, R., \& Vanhove, N. (1994). The competitive situation of tourism in the Caribbean area methodological approach. Tourism Review, 49(3), 19-22.

Deng, J., King, B., \& Bauer, T. (2002). Evaluating natural attractions for tourism. Annals of Tourism Research, $29(2), 422-438$.

Dillman, D. A. (1978). Mail and telephone surveys: The total design method. New York, NY: Wiley-Interscience.

Dwyer, L., \& Kim, C. (2003). Destination competitiveness: determinants and indicators. Current issues in 
tourism, 6(5), 369-414.

Dwyer, L., Forsyth, P., \& Rao, P. (2000). The price competitiveness of travel and tourism: a comparison of 19 destinations. Tourism Management, 21(1), 9-22.

Dwyer, L., Livaic, Z., \& Mellor, R. (2003).Competitiveness of Australia as a tourist destination. Journal of Hospitality and Tourism Management, 10, 60-78.

Echtner, C. M., \& Ritchie, J. B. (1991). The meaning and measurement of destination image. Journal of tourism studies, 2(2), 2-12.

Enright, M. J., \& Newton, J. (2004). Tourism destination competitiveness: a quantitative approach. Tourism Management, 25(6), 777-788.

Enright, M. J., Scott, E. E., \& Dodwell, D. (1997). The Hong Kong Advantage. OUP Catalogue, Oxford University Press.

Gomezelj, D. O., \& Mihalič, T. (2008). Destination competitiveness-Applying different models, the case of Slovenia. Tourism management, 29(2), 294-307.

Frei, F. X., \& Harker, P. T. (1999). Measuring aggregate process performance using AHP. European Journal of Operational Research, 116(2), 436-442.

Hassan, S. S. (2000).Determinants of market competitiveness in an environmentally sustainable tourism industry. Journal of travel research, 38(3), 239-245.

Hsu, T. K., Tsai, Y. F., \& Wu, H. H. (2009). The preference analysis for tourist choice of destination: A case study of Taiwan. Tourism Management, 30(2), 288-297.

Huang, Y., \& Bian, L. (2009). A Bayesian network and analytic hierarchy process based personalized recommendations for tourist attractions over the Internet. Expert Systems with Applications, 36(1), 933-943. 
Ishizaka, A., \& Labib, A. (2011). Review of the main developments in the analytic hierarchy process. Expert Systems with Applications, 38(11), 14336-14345.

Kao, C., Wu, W. Y., Hsieh, W. J., Wang, T. Y., Lin, C., \& Chen, L. H. (2008). Measuring the national competitiveness of Southeast Asian countries. European Journal of Operational Research, 187(2), 613-628.

Kim, S. S., Guo, Y., \& Agrusa, J. (2005). Preference and positioning analyses of overseas destinations by mainland Chinese outbound pleasure tourists. Journal of Travel Research, 44(2), 212-220.

Kozak, M., \& Rimmington, M. (1999). Measuring tourist destination competitiveness: conceptual considerations and empirical findings. International Journal of Hospitality Management, 18(3), 273-283.

Kwak, N. K., \& Lee, C. W. (2002). Business process reengineering for health-care system using multicriteria mathematical programming. European Journal of Operational Research, 140(2), 447-458.

Lall, S. (2001). Competitiveness indices and developing countries: an economic evaluation of the global competitiveness report. World development, 29(9), 1501-1525.

Lee, S. K., Mogi, G., \& Kim, J. W. (2008). The competitiveness of Korea as a developer of hydrogen energy technology: the AHP approach. Energy policy, 36(4), 1284-1291.

Mihalič, T. (2000). Environmental management of a tourist destination: A factor of tourism competitiveness. Tourism Management, 21(1), 65-78.

Newall, J. E. (1992). The challenge of competitiveness. Business Quarterly, 56(4), 94-100

Jaber, J. O, \& Mohsen, M.S. (2001). Evaluation of non-conventional water resources supply in Jordan. Desalination, 136(1), 83-92.

Osmanković, J., Kenjić, V., \& Zrnić, R. (2010). Destination management: consensus for competitiveness. 
Proceedings of the 20th Biennal International Congress Tourism and Hospitality Management (pp. $513-526)$.

Peng, M.W. (2001). The resource-based view and international business. Journal of Management, 27(6), 803-829.

Porter, M.E. (1990). The competitive advantage of nations. Harvard business review, 68(2), 73-93.

Ramanathan, R. (2001). A note on the use of the analytic hierarchy process for environmental impact assessment. Journal of Environmental Management, 63(1), 27-35.

Ritchie, J. R., \& Crouch, G. I. (2003).The competitive destination: A sustainable tourism perspective. Cabi.

Roberts, B., \& Stimson, R. J. (1998). Multi-sectoral qualitative analysis: a tool for assessing the competitiveness of regions and formulating strategies for economic development. The Annals of Regional Science, $32(4), 469-494$.

Saaty, T.L. (1980). The analytic hierarchy process. New York, NY: McGraw.

Saaty, T. L. (1988). What is the analytic hierarchy process? Springer Berlin Heidelberg.

Schniederjans, M. J., \& Wilson, R. L. (1991). Using the analytic hierarchy process and goal programming for information system project selection. Information \& Management, 20(5), 333-342.

Scott, B. R., \& Lodge, G. C. (1985). US competitiveness in the world economy. The International Executive, $27(1), 26-26$.

Sirse, J., \& Mihalic, T. (1999). Slovenian tourism and tourism policy: A case study. Tourism Review, 54(3), $34-47$.

Suwignjo, P., Bititci, U. S., \& Carrie, A. S. (2000). Quantitative models for performance measurement system. International Journal of Production Economics, 64(1), 231-241. 
Troutt, M. D., \& Tadisina, S. K. (1992). The analytic hierarchy process as a model base for a merit salary recommendation system. Mathematical and computer modelling, 16(5), 99-105.

Tseng, H. P., \& Chen, C. H. (2013, July). Exploration of Destination Competitiveness Framework--City as a Destination. In Complex, Intelligent, and Software Intensive Systems (CISIS), 2013 Seventh International Conference (pp. 673-676). IEEE.

U.S. Travel Association. (2012). The economic impact of the travel industry. Retrieved June 25, 2014 from http://traveleffect.com/economy

U.S. Travel Association. (2014). U.S. Travel Forecasts. Retrieved June 25, 2014 from http://www.ustravel.org/research/travel-industry-forecasts

Viswanadhan, K. G. (2005). How to get responses for multi-criteria decisions in engineering education-an AHP based approach for selection of measuring instrument. Financial Support, 20.

Viswanadhan, K. G. (2009). Quality indicators of engineering education programmes: a multi-criteria analysis from India. International Journal of Industrial and Systems Engineering, 4(3), 270-282.

Wang, J. (2008). Development of outdoor recreation resource amenity indices for West Virginia (Doctoral dissertation, West Virginia University).

Wernerfelt, B. (1984). A resource-based view of the firm. Strategic management journal, 5(2), 171-180.

Yedla, S., \& Shrestha, R. M. (2003). Multi-criteria approach for the selection of alternative options for environmentally sustainable transport system in Delhi. Transportation Research Part A: Policy and Practice, 37(8), 717-729 


\section{Appendix A}

Table A1

Top 10 Important Destination Attributes and Determinant Destination Attributes

\begin{tabular}{|c|c|c|c|c|}
\hline Attributes & $\begin{array}{l}\text { Global } \\
\text { Importance } \\
\text { Weights }\end{array}$ & $\begin{array}{l}\text { Importance } \\
\text { Rank }\end{array}$ & $\begin{array}{l}\text { Global } \\
\text { Determinance } \\
\text { Weights }\end{array}$ & $\begin{array}{l}\text { Determinance } \\
\text { Rank }\end{array}$ \\
\hline Special events & 0.267 & 2 & 0.076946 & 6 \\
\hline $\begin{array}{l}\text { Physiography and } \\
\text { climate }\end{array}$ & 0.328 & 1 & 0.142032 & 1 \\
\hline Culture and history & 0.0425 & 4 & 0.113747 & 2 \\
\hline Mix of activities & 0.0451 & 3 & 0.105535 & 4 \\
\hline Superstructure & 0.0388 & 5 & 0.109489 & 3 \\
\hline Accessibility & 0.0345 & 8 & 0.07056 & 9 \\
\hline Awareness/image & 0.0320 & 9 & 0.08972 & 5 \\
\hline Location & 0.0313 & 10 & & \\
\hline Safety and Security & 0.0369 & 6 & & \\
\hline Cost Value & 0.0346 & 7 & & \\
\hline Entertainment & & & 0.075426 & 7 \\
\hline Infrastructure & & & 0.071776 & 8 \\
\hline Positioning and branding & & & 0.067518 & 10 \\
\hline
\end{tabular}

Note. The table was formed based on the study of Crouch (2011). 


\section{Appendix B}

Dear XXX:

My name is Yanhong Zhou, a graduate student in the department of Recreation, Parks and Tourism Resources at West Virginia University. I am writing to request your expert input for my thesis research on competitiveness evaluation of West Virginia as tourism destination. I expect to graduate in August 2014, and I am currently collecting data for my thesis in partial fulfillment of the requirements for my graduation.

Since you are a tourism expert and practitioner in West Virginia, I am requesting your most valued opinion on the relative importance of various tourism attributes in the State of West Virginia in order to effectively evaluate the State's tourism competitiveness in relation to other destinations. Analytical Hierarchy Process (AHP)-the method I am applying in my thesis requires input from destination's tourism experts, such as you, on relative importance of the destination's attributes through pairwise comparisons. Specific instructions on completing the survey are provided on the first page of the survey.

To complete this study, I am requesting you to:

(1) Download the attached word file.

(2) Fill the survey.

(3) Save it and email back to me via this email yazhou@mix.wvu.edu.

If you need further assistance completing the survey, or prefer completing it in another way (including hard copy or face-to-face interview) please let me know. My complete contact details are included below.

Since I will need to complete this study in time to graduate in August 2014, I would appreciate if you could send me your response by May 15, 2014.

Thank you in advance for your participation.

Sincerely,

Yanhong Zhou

Graduate Student

322 Percival Hall

Recreation, Parks \& Tourism Resources Program

Division of Forestry \& Natural Resources

West Virginia University, Morgantown, WV 26505

Tel: (740)590-9244; Email: yazhou@mix.wvu.edu 


\section{Appendix C}

Pairwise Comparison of Tourism Attributes: An Analytical Hierarchical Process

The purpose of this survey is to determine the relative importance of tourism attributes that represent a destination's tourism competitiveness. To achieve this goal, I need expert opinion on relative importance of these attributes. Please follow the instruction below to complete this survey. Your input is valued and appreciated. Your identity will be kept confidential. It will take you about 10-15 minutes to complete this survey.

Before you start, please take a look at the following instructions you will use to complete the pairwise comparison.

\begin{tabular}{|l|l|}
\hline $\begin{array}{l}\text { Intensity of } \\
\text { Importance }\end{array}$ & Determination and Explanation \\
\hline 1 & Two attributes are equally important \\
\hline 3 & One attribute is slightly more important than the other \\
\hline 5 & One attribute is moderately important over the other \\
\hline 7 & One attribute is very important over the other \\
\hline 9 & One attribute is extremely important over the other \\
\hline
\end{tabular}

Source: Satty (1988)

For example, the following hypothetical comparison shows the relative importance of attributes when one plans to visit a destination. In this pairwise comparison, the respondent thinksthat history is slightly more important than nature ( 3 is then checked on the side of history), and friendliness is very important than history ( 7 is then checked on the side of friendliness). Note: 1 is the benchmark. If you check a number on the left, it means that the attribute on the left side is more important. Likewise, if you check a number on the right, the attribute on this side is more important.

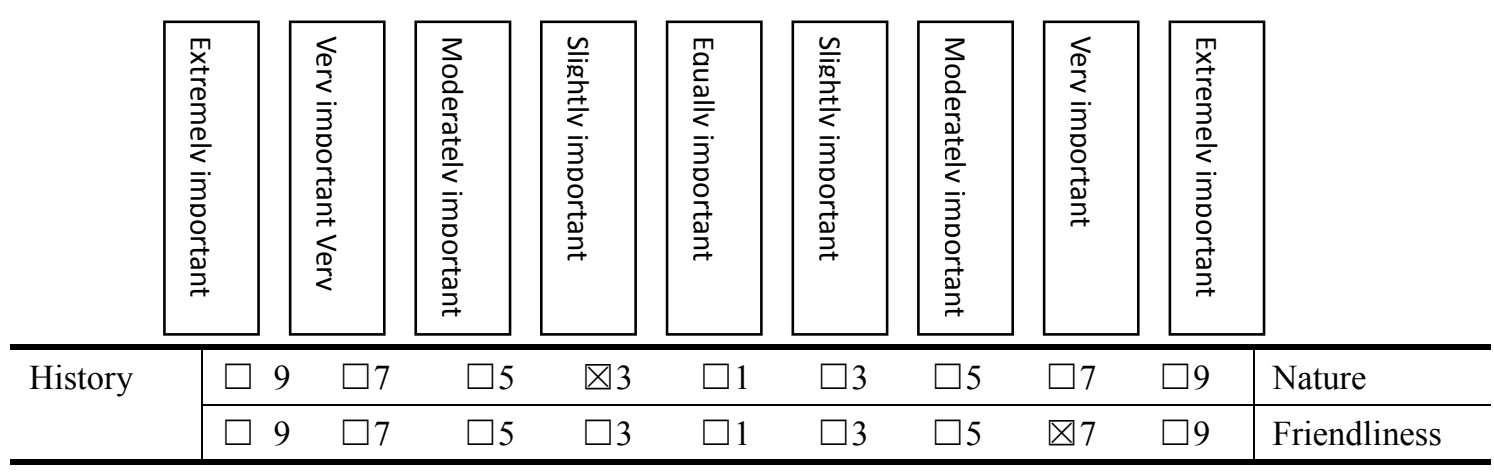

Please rate the relative importance of tourism attributes based on your knowledge and experience in the tourism field in the following pages. 
Section 1 Please rate attributes that represent supporting factors.

\begin{tabular}{|c|c|c|c|c|c|c|c|c|c|c|}
\hline & 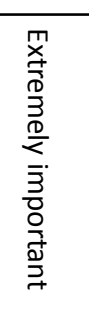 & 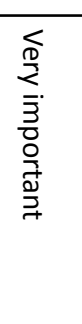 & 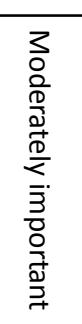 & 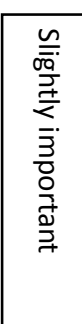 & 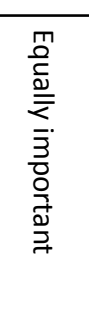 & 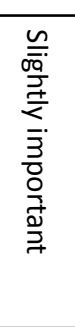 & 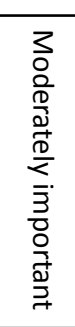 & 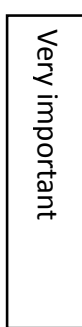 & 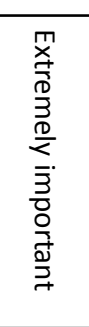 & \\
\hline \multirow{6}{*}{$\begin{array}{l}\text { Value for money } \\
\text { in shopping items }\end{array}$} & $\square 9$ & $\square 7$ & $\square 5$ & $\square 3$ & $\square 1$ & $\square 3$ & $\square 5$ & $\square 7$ & $\square 9$ & $\begin{array}{l}\text { Variety and quality of } \\
\text { restaurants }\end{array}$ \\
\hline & $\square 9$ & $\square 7$ & $\square 5$ & $\square 3$ & $\square 1$ & $\square 3$ & $\square 5$ & $\square 7$ & $\square 9$ & $\begin{array}{l}\text { Variety and quality of } \\
\text { accommodation }\end{array}$ \\
\hline & $\square 9$ & $\square 7$ & $\square 5$ & $\square 3$ & $\square 1$ & $\square 3$ & $\square 5$ & $\square 7$ & $\square 9$ & Local transportation efficiency \\
\hline & $\square 9$ & $\square 7$ & $\square 5$ & $\square 3$ & $\square 1$ & $\square 3$ & $\square 5$ & $\square 7$ & $\square 9$ & Communication facilities \\
\hline & $\square 9$ & $\square 7$ & $\square 5$ & $\square 3$ & $\square 1$ & $\square 3$ & $\square 5$ & $\square 7$ & $\square 9$ & Road condition \\
\hline & $\square 9$ & $\square 7$ & $\square 5$ & $\square 3$ & $\square 1$ & $\square 3$ & $\square 5$ & $\square 7$ & $\square 9$ & Shopping facilities \\
\hline \multirow{5}{*}{$\begin{array}{l}\text { Variety and } \\
\text { quality of } \\
\text { restaurants }\end{array}$} & $\square 9$ & $\square 7$ & $\square 5$ & $\square 3$ & $\square 1$ & $\square 3$ & $\square 5$ & $\square 7$ & $\square 9$ & $\begin{array}{l}\text { Variety and quality of } \\
\text { accommodation }\end{array}$ \\
\hline & $\square 9$ & $\square 7$ & $\square 5$ & $\square 3$ & $\square 1$ & $\square 3$ & $\square 5$ & $\square 7$ & $\square 9$ & Local transportation efficiency \\
\hline & $\square 9$ & $\square 7$ & $\square 5$ & $\square 3$ & $\square 1$ & $\square 3$ & $\square 5$ & $\square 7$ & $\square 9$ & Communication facilities \\
\hline & $\square 9$ & $\square 7$ & $\square 5$ & $\square 3$ & $\square 1$ & $\square 3$ & $\square 5$ & $\square 7$ & $\square 9$ & Road condition \\
\hline & $\square 9$ & $\square 7$ & $\square 5$ & $\square 3$ & $\square 1$ & $\square 3$ & $\square 5$ & $\square 7$ & $\square 9$ & Shopping facilities \\
\hline \multirow{4}{*}{$\begin{array}{l}\text { Variety and } \\
\text { quality of } \\
\text { accommodation }\end{array}$} & $\square 9$ & $\square 7$ & $\square 5$ & $\square 3$ & $\square 1$ & $\square 3$ & $\square 5$ & $\square 7$ & $\square 9$ & Local transportation efficiency \\
\hline & $\square 9$ & $\square 7$ & $\square 5$ & $\square 3$ & $\square 1$ & $\square 3$ & $\square 5$ & $\square 7$ & $\square 9$ & Communication facilities \\
\hline & $\square 9$ & $\square 7$ & $\square 5$ & $\square 3$ & $\square 1$ & $\square 3$ & $\square 5$ & $\square 7$ & $\square 9$ & Road condition \\
\hline & $\square 9$ & $\square 7$ & $\square 5$ & $\square 3$ & $\square 1$ & $\square 3$ & $\square 5$ & $\square 7$ & $\square 9$ & Shopping facilities \\
\hline \multirow{3}{*}{$\begin{array}{l}\text { Local } \\
\text { transportation } \\
\text { efficiency }\end{array}$} & $\square 9$ & $\square 7$ & $\square 5$ & $\square 3$ & $\square 1$ & $\square 3$ & $\square 5$ & $\square 7$ & $\square 9$ & Communication facilities \\
\hline & $\square 9$ & $\square 7$ & $\square 5$ & $\square 3$ & $\square 1$ & $\square 3$ & $\square 5$ & $\square 7$ & $\square 9$ & Road condition \\
\hline & $\square 9$ & $\square 7$ & $\square 5$ & $\square 3$ & $\square 1$ & $\square 3$ & $\square 5$ & $\square 7$ & $\square 9$ & Shopping facilities \\
\hline \multirow{2}{*}{$\begin{array}{l}\text { Communication } \\
\text { facilities }\end{array}$} & $\square 9$ & $\square 7$ & $\square 5$ & $\square 3$ & $\square 1$ & $\square 3$ & $\square 5$ & $\square 7$ & $\square 9$ & Road condition \\
\hline & $\square 9$ & $\square 7$ & $\square 5$ & $\square 3$ & $\square 1$ & $\square 3$ & $\square 5$ & $\square 7$ & $\square 9$ & Shopping facilities \\
\hline Road condition & $\square 9$ & $\square 7$ & $\square 5$ & $\square 3$ & $\square 1$ & $\square 3$ & $\square 5$ & $\square 7$ & $\square 9$ & Shopping facilities \\
\hline
\end{tabular}


Section 2 Please rate attributes that represent core resources.

\begin{tabular}{|c|c|c|c|c|c|c|c|c|c|c|c|}
\hline & 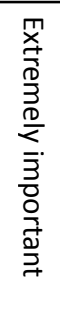 & & 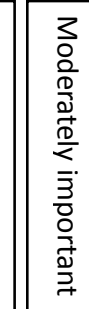 & 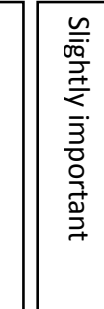 & & 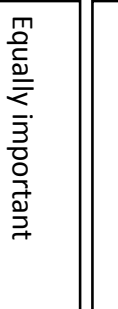 & 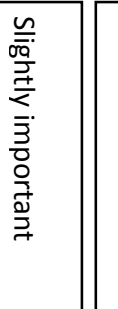 & 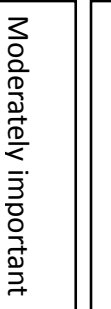 & 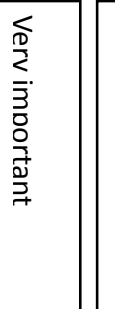 & 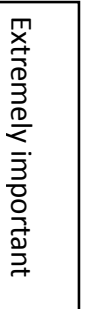 & \\
\hline \multirow{3}{*}{\multicolumn{2}{|c|}{$\begin{array}{l}\text { Nature-based } \\
\text { activities }\end{array}$}} & $\square 9$ & $\square 7$ & $\square 5$ & $\square 3$ & $\square 1$ & $\square 3$ & $\square 5$ & $\square 7$ & $\square 9$ & $\begin{array}{l}\text { Value for money in tourism } \\
\text { experiences }\end{array}$ \\
\hline & & $\square 9$ & $\square 7$ & $\square 5$ & $\square 3$ & $\square 1$ & $\square 3$ & $\square 5$ & $\square 7$ & $\square 9$ & $\begin{array}{l}\text { Availability of } \\
\text { adventure-based activities }\end{array}$ \\
\hline & & $\square 9$ & $\square 7$ & $\square 5$ & $\square 3$ & $\square 1$ & $\square 3$ & $\square 5$ & $\square 7$ & $\square 9$ & Good weather/climate \\
\hline \multirow{2}{*}{\multicolumn{2}{|c|}{$\begin{array}{l}\text { Value for } \\
\text { money in } \\
\text { tourism } \\
\text { experiences }\end{array}$}} & $\square 9$ & $\square 7$ & $\square 5$ & $\square 3$ & $\square 1$ & $\square 3$ & $\square 5$ & $\square 7$ & $\square 9$ & $\begin{array}{l}\text { Availability of } \\
\text { adventure-based activities }\end{array}$ \\
\hline & & $\square 9$ & $\square 7$ & $\square 5$ & $\square 3$ & $\square 1$ & $\square 3$ & $\square 5$ & $\square 7$ & $\square 9$ & Good weather/climate \\
\hline \multicolumn{2}{|c|}{$\begin{array}{l}\text { Availability of } \\
\text { adventure-based } \\
\text { activities }\end{array}$} & $\square 9$ & $\square 7$ & $\square 5$ & $\square 3$ & $\square 1$ & $\square 3$ & $\square 5$ & $\square 7$ & $\square 9$ & Good weather/climate \\
\hline
\end{tabular}

Section 3 Please rate attributes that represent attractions and their accessibility.
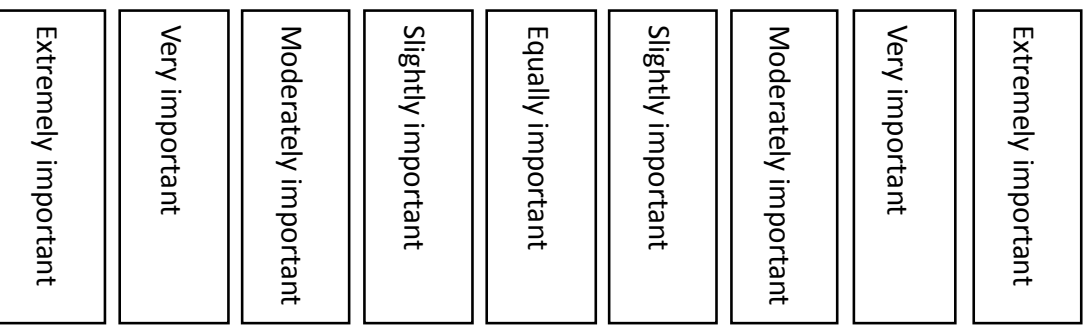

\begin{tabular}{lllllllll|l}
$\square 9$ & $\square 7$ & $\square 5$ & $\square 3$ & $\square 1$ & $\square 3$ & $\square 5$ & $\square 7$ & $\square 9$ & Dedicated tourism attractions \\
$\square 9$ & $\square 7$ & $\square 5$ & $\square 3$ & $\square 1$ & $\square 3$ & $\square 5$ & $\square 7$ & $\square 9$ & Special events \\
$\square 9$ & $\square 7$ & $\square 5$ & $\square 3$ & $\square 1$ & $\square 3$ & $\square 5$ & $\square 7$ & $\square 9$ & Interesting architecture \\
$\square 9$ & $\square 7$ & $\square 5$ & $\square 3$ & $\square 1$ & $\square 3$ & $\square 5$ & $\square 7$ & $\square 9$ & Historic sites \\
$\square 9$ & $\square 7$ & $\square 5$ & $\square 3$ & $\square 1$ & $\square 3$ & $\square 5$ & $\square 7$ & $\square 9$ & Availability of activities for \\
children
\end{tabular}

Well-known landmarks 


\begin{tabular}{|c|c|c|c|c|c|c|c|c|c|c|}
\hline \multirow{7}{*}{$\begin{array}{l}\text { Dedicated } \\
\text { tourism } \\
\text { attractions }\end{array}$} & $\square 9$ & $\square 7$ & $\square 5$ & $\square 3$ & $\square 1$ & $\square 3$ & $\square 5$ & $\square 7$ & $\square 9$ & Special events \\
\hline & $\square 9$ & $\square 7$ & $\square 5$ & $\square 3$ & $\square 1$ & $\square 3$ & $\square 5$ & $\square 7$ & $\square 9$ & Interesting architecture \\
\hline & $\square 9$ & $\square 7$ & $\square 5$ & $\square 3$ & $\square 1$ & $\square 3$ & $\square 5$ & $\square 7$ & $\square 9$ & Historic sites \\
\hline & $\square 9$ & $\square 7$ & $\square 5$ & $\square 3$ & $\square 1$ & $\square 3$ & $\square 5$ & $\square 7$ & $\square 9$ & $\begin{array}{l}\text { Availability of activities for } \\
\text { children }\end{array}$ \\
\hline & $\square 9$ & $\square 7$ & $\square 5$ & $\square 3$ & $\square 1$ & $\square 3$ & $\square 5$ & $\square 7$ & $\square 9$ & Conveniently located \\
\hline & $\square 9$ & $\square 7$ & $\square 5$ & $\square 3$ & $\square 1$ & $\square 3$ & $\square 5$ & $\square 7$ & $\square 9$ & Availability of tourist information \\
\hline & $\square 9$ & $\square 7$ & $\square 5$ & $\square 3$ & $\square 1$ & $\square 3$ & $\square 5$ & $\square 7$ & $\square 9$ & Variety of activities to do \\
\hline \multirow{6}{*}{ Special events } & $\square 9$ & $\square 7$ & $\square 5$ & $\square 3$ & $\square 1$ & $\square 3$ & $\square 5$ & $\square 7$ & $\square 9$ & Interesting architecture \\
\hline & $\square 9$ & $\square 7$ & $\square 5$ & $\square 3$ & $\square 1$ & $\square 3$ & $\square 5$ & $\square 7$ & $\square 9$ & Historic sites \\
\hline & $\square 9$ & $\square 7$ & $\square 5$ & $\square 3$ & $\square 1$ & $\square 3$ & $\square 5$ & $\square 7$ & $\square 9$ & $\begin{array}{l}\text { Availability of activities for } \\
\text { children }\end{array}$ \\
\hline & $\square 9$ & $\square 7$ & $\square 5$ & $\square 3$ & $\square 1$ & $\square 3$ & $\square 5$ & $\square 7$ & $\square 9$ & Conveniently located \\
\hline & $\square 9$ & $\square 7$ & $\square 5$ & $\square 3$ & $\square 1$ & $\square 3$ & $\square 5$ & $\square 7$ & $\square 9$ & Availability of tourist information \\
\hline & $\square 9$ & $\square 7$ & $\square 5$ & $\square 3$ & $\square 1$ & $\square 3$ & $\square 5$ & $\square 7$ & $\square 9$ & Variety of activities to do \\
\hline \multirow{5}{*}{$\begin{array}{l}\text { Interesting } \\
\text { architecture }\end{array}$} & $\square 9$ & $\square 7$ & $\square 5$ & $\square 3$ & $\square 1$ & $\square 3$ & $\square 5$ & $\square 7$ & $\square 9$ & Historic sites \\
\hline & $\square 9$ & $\square 7$ & $\square 5$ & $\square 3$ & $\square 1$ & $\square 3$ & $\square 5$ & $\square 7$ & $\square 9$ & $\begin{array}{l}\text { Availability of activities for } \\
\text { children }\end{array}$ \\
\hline & $\square 9$ & $\square 7$ & $\square 5$ & $\square 3$ & $\square 1$ & $\square 3$ & $\square 5$ & $\square 7$ & $\square 9$ & Conveniently located \\
\hline & $\square 9$ & $\square 7$ & $\square 5$ & $\square 3$ & $\square 1$ & $\square 3$ & $\square 5$ & $\square 7$ & $\square 9$ & Availability of tourist information \\
\hline & $\square 9$ & $\square 7$ & $\square 5$ & $\square 3$ & $\square 1$ & $\square 3$ & $\square 5$ & $\square 7$ & $\square 9$ & Variety of activities to do \\
\hline \multirow{4}{*}{ Historic sites } & $\square 9$ & $\square 7$ & $\square 5$ & $\square 3$ & $\square 1$ & $\square 3$ & $\square 5$ & $\square 7$ & $\square 9$ & $\begin{array}{l}\text { Availability of activities for } \\
\text { children }\end{array}$ \\
\hline & $\square 9$ & $\square 7$ & $\square 5$ & $\square 3$ & $\square 1$ & $\square 3$ & $\square 5$ & $\square 7$ & $\square 9$ & Conveniently located \\
\hline & $\square 9$ & $\square 7$ & $\square 5$ & $\square 3$ & $\square 1$ & $\square 3$ & $\square 5$ & $\square 7$ & $\square 9$ & Availability of tourist information \\
\hline & $\square 9$ & $\square 7$ & $\square 5$ & $\square 3$ & $\square 1$ & $\square 3$ & $\square 5$ & $\square 7$ & $\square 9$ & Variety of activities to do \\
\hline \multirow{3}{*}{$\begin{array}{l}\text { Availability of } \\
\text { activities for } \\
\text { children }\end{array}$} & $\square 9$ & $\square 7$ & $\square 5$ & $\square 3$ & $\square 1$ & $\square 3$ & $\square 5$ & $\square 7$ & $\square 9$ & Conveniently located \\
\hline & $\square 9$ & $\square 7$ & $\square 5$ & $\square 3$ & $\square 1$ & $\square 3$ & $\square 5$ & $\square 7$ & $\square 9$ & Availability of tourist information \\
\hline & $\square 9$ & $\square 7$ & $\square 5$ & $\square 3$ & $\square 1$ & $\square 3$ & $\square 5$ & $\square 7$ & $\square 9$ & Variety of activities to do \\
\hline \multirow{2}{*}{$\begin{array}{l}\text { Conveniently } \\
\text { located }\end{array}$} & $\square 9$ & $\square 7$ & $\square 5$ & $\square 3$ & $\square 1$ & $\square 3$ & $\square 5$ & $\square 7$ & $\square 9$ & Availability of tourist information \\
\hline & $\square 9$ & $\square 7$ & $\square 5$ & $\square 3$ & $\square 1$ & $\square 3$ & $\square 5$ & $\square 7$ & $\square 9$ & Variety of activities to do \\
\hline $\begin{array}{l}\text { Availability of } \\
\text { tourist } \\
\text { information }\end{array}$ & $\square 9$ & $\square 7$ & $\square 5$ & $\square 3$ & $\square 1$ & $\square 3$ & $\square 5$ & $\square 7$ & $\square 9$ & Variety of activities to do \\
\hline
\end{tabular}


Section 4 Please rate attributes that represent qualifying and amplifying Determinants (Refer to factors that moderate, modify, mitigate and filter, or magnify, strengthen, enhance and augment the impact of all other determinants)

\begin{tabular}{|c|c|c|c|c|c|c|c|c|c|c|}
\hline & 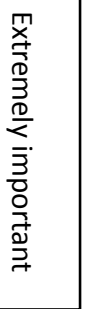 & 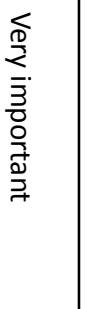 & 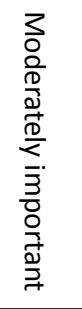 & 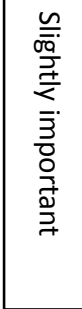 & 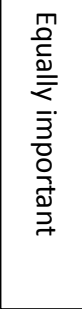 & 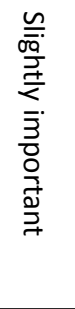 & 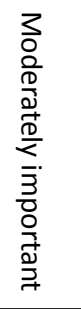 & 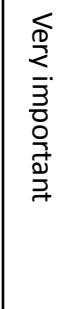 & 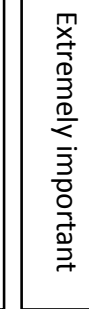 & \\
\hline \multirow{4}{*}{$\begin{array}{l}\text { Hospitality \& } \\
\text { friendliness of } \\
\text { residents }\end{array}$} & $\square 9$ & $\square 7$ & $\square 5$ & $\square 3$ & $\square 1$ & $\square 3$ & $\square 5$ & $\square 7$ & $\square 9$ & Safety \&security \\
\hline & $\square 9$ & $\square 7$ & $\square 5$ & $\square 3$ & $\square 1$ & $\square 3$ & $\square 5$ & $\square 7$ & $\square 9$ & Cleanliness \\
\hline & $\square 9$ & $\square 7$ & $\square 5$ & $\square 3$ & $\square 1$ & $\square 3$ & $\square 5$ & $\square 7$ & $\square 9$ & $\begin{array}{l}\text { Well marked } \\
\text { roads/attractions }\end{array}$ \\
\hline & $\square 9$ & $\square 7$ & $\square 5$ & $\square 3$ & $\square 1$ & $\square 3$ & $\square 5$ & $\square 7$ & $\square 9$ & $\begin{array}{l}\text { Accessibility of } \\
\text { destination }\end{array}$ \\
\hline \multirow{3}{*}{$\begin{array}{l}\text { Safety \& } \\
\text { Security }\end{array}$} & $\square 9$ & $\square 7$ & $\square 5$ & $\square 3$ & $\square 1$ & $\square 3$ & $\square 5$ & $\square 7$ & $\square 9$ & Cleanliness \\
\hline & $\square 9$ & $\square 7$ & $\square 5$ & $\square 3$ & $\square 1$ & $\square 3$ & $\square 5$ & $\square 7$ & $\square 9$ & $\begin{array}{l}\text { Well marked } \\
\text { roads/attractions }\end{array}$ \\
\hline & $\square 9$ & $\square 7$ & $\square 5$ & $\square 3$ & $\square 1$ & $\square 3$ & $\square 5$ & $\square 7$ & $\square 9$ & $\begin{array}{l}\text { Accessibility of } \\
\text { destination }\end{array}$ \\
\hline \multirow[t]{2}{*}{ Cleanliness } & $\square 9$ & $\square 7$ & $\square 5$ & $\square 3$ & $\square 1$ & $\square 3$ & $\square 5$ & $\square 7$ & $\square 9$ & $\begin{array}{l}\text { Well marked } \\
\text { roads/attractions }\end{array}$ \\
\hline & $\square 9$ & $\square 7$ & $\square 5$ & $\square 3$ & $\square 1$ & $\square 3$ & $\square 5$ & $\square 7$ & $\square 9$ & $\begin{array}{l}\text { Accessibility of } \\
\text { destination }\end{array}$ \\
\hline $\begin{array}{l}\text { Well marked } \\
\text { roads/attraction } \\
\mathrm{s}\end{array}$ & $\square 9$ & $\square 7$ & $\square 5$ & $\square 3$ & $\square 1$ & $\square 3$ & $\square 5$ & $\square 7$ & $\square 9$ & $\begin{array}{l}\text { Accessibility of } \\
\text { destination }\end{array}$ \\
\hline
\end{tabular}


Section 5 Please rate the relative importance of the four main categories you just went through. Please see the following table for your convenience if you need to know what the four categories are.

\begin{tabular}{|c|c|c|c|}
\hline $\begin{array}{l}\text { Supporting factors } \\
\text { and facilities }\end{array}$ & Core resources & $\begin{array}{l}\text { Attractions and } \\
\text { accessibility }\end{array}$ & $\begin{array}{l}\text { Qualifying and } \\
\text { amplifying } \\
\text { determinants }\end{array}$ \\
\hline $\begin{array}{l}\text { 1. Value for money } \\
\text { in shopping items } \\
\text { 2. Variety and } \\
\text { quality of } \\
\text { restaurants } \\
\text { 3. Variety and } \\
\text { quality of } \\
\text { accommodation } \\
\text { 4. Local } \\
\text { transportation } \\
\text { efficiency } \\
\text { 5. Communication } \\
\text { facilities } \\
\text { 6. Road condition } \\
\text { 7. Shopping facilities }\end{array}$ & $\begin{array}{l}\text { 1. Nature-based } \\
\text { activities } \\
\text { 2. Value for money in } \\
\text { tourism } \\
\text { experiences } \\
\text { 3. Availability of } \\
\text { adventure-based } \\
\text { activities } \\
\text { 4. Good } \\
\text { weather/climate }\end{array}$ & $\begin{array}{l}\text { 1. Well-known } \\
\text { landmarks } \\
\text { 2. Dedicated tourism } \\
\text { attractions } \\
\text { 3. Special events } \\
\text { 4. Interesting } \\
\text { Architecture } \\
\text { 5. Historic sites } \\
\text { 6. Availability of } \\
\text { activities for children } \\
\text { 7. Conveniently located } \\
\text { 8. Availability of tourist } \\
\text { information } \\
\text { 9. Variety of activities to } \\
\text { do }\end{array}$ & $\begin{array}{l}\text { 1. Hospitality \& } \\
\text { friendliness of } \\
\text { residents } \\
\text { 2. Safety and security } \\
\text { 3. Cleanliness } \\
\text { 4. Well marked } \\
\text { roads/attractions } \\
\text { Accessibility of } \\
\text { destination }\end{array}$ \\
\hline
\end{tabular}

\begin{tabular}{|c|c|c|c|c|c|c|c|c|c|c|}
\hline & 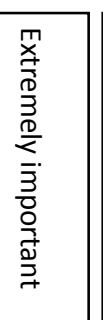 & 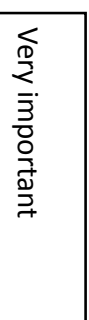 & 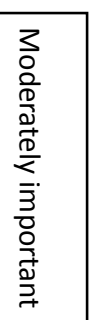 & 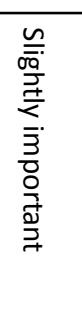 & 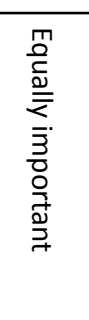 & 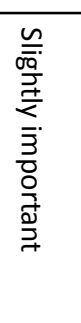 & 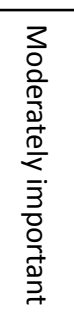 & 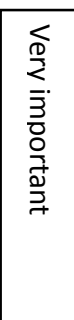 & 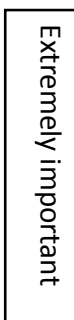 & \\
\hline \multirow{3}{*}{$\begin{array}{l}\text { Supporting } \\
\text { factors \& } \\
\text { facilities }\end{array}$} & $\square 9$ & $\square 7$ & $\square 5$ & $\square 3$ & $\square 1$ & $\square 3$ & $\square 5$ & $\square 7$ & $\square 9$ & Core resources \\
\hline & $\square 9$ & $\square 7$ & $\square 5$ & $\square 3$ & $\square 1$ & $\square 3$ & $\square 5$ & $\square 7$ & $\square 9$ & Attractions \& their accessibility \\
\hline & $\square 9$ & $\square 7$ & $\square 5$ & $\square 3$ & $\square 1$ & $\square 3$ & $\square 5$ & $\square 7$ & $\square 9$ & $\begin{array}{l}\text { Qualifying \& amplifying } \\
\text { determinants }\end{array}$ \\
\hline \multirow[b]{2}{*}{ Core resources } & $\square 9$ & $\square 7$ & $\square 5$ & $\square 3$ & $\square 1$ & $\square 3$ & $\square 5$ & $\square 7$ & $\square 9$ & Attractions \& their accessibility \\
\hline & $\square 9$ & $\square 7$ & $\square 5$ & $\square 3$ & $\square 1$ & $\square 3$ & $\square 5$ & $\square 7$ & $\square 9$ & $\begin{array}{l}\text { Qualifying \& amplifying } \\
\text { determinants }\end{array}$ \\
\hline $\begin{array}{l}\text { Attractions \& } \\
\text { their accessibility }\end{array}$ & $\square 9$ & $\square 7$ & $\square 5$ & $\square 3$ & $\square 1$ & $\square 3$ & $\square 5$ & $\square 7$ & $\square 9$ & $\begin{array}{l}\text { Qualifying \& amplifying } \\
\text { determinants }\end{array}$ \\
\hline
\end{tabular}


Section 6 Demographics

1. Gender $\square$ Male $\square$ Female

2. Which of the following age group represents your age?

$\square$ 18-30 $\square 31-40 \quad \square$ 41-50 $\square$ 51-60 $\square$ 61-70 $\square$ over 70

3. How many years of experience do you have in the tourism field?

$\square$ 1-3 years $\square$ 4-6 years $\square$ 6-9years $\square$ 9-12 years $\square$ 13-15years $\square$ more than 15 years

4. Have you worked in other States before?

$\square$ Yes, if yes, how many years did you work in the tourism field before you worked for WV? $\square$ 1-3 years $\square$ 4-6 years $\square$ 6-9years $\square$ 9-12 years $\square$ 13-15years $\square$ more than 15 years

$\square$ No

5. Please indicate your highest level of education you have completed

$\square$ High school diploma

$\square$ Undergraduate or post-secondary degree

$\square$ Graduate degree

Thank You for Your Participation! 


\section{Appendix D}

\section{Dear XXX:}

I am writing to follow up on the email I sent you on April 25, 2014 regarding my master's thesis study.

My study evaluates West Virginia's tourism competitiveness. the results from this study will have significant management implications providing valuable insights into what tourism attributes are the most and least important to tourism development and growth in the state of WV. Such information will be useful to destination management and marketers as they make important decisions on what aspects of the destination to focus and commit development and marketing resources on. An executive summary highlighting all critical findings, recommendations and destination management implications will be sent to all participants after the study is completed.

I can also make arrangements to come over and meet with you at your convenience, if you prefer a face-to-face interview. I will be calling you on Friday (May 9, 2014) to make an appointment to meet with you, if I have not heard from you by that time.

You can find the survey attached in this email.

Your input is greatly appreciated, and I will be looking forward to hearing from you.

Sincerely,

Yanhong Zhou

Graduate Student

322 Percival Hall

Recreation, Parks \& Tourism Resources Program

Division of Forestry \& Natural Resources

West Virginia University, Morgantown, WV 26505

Tel: (740)590-9244; Email: yazhou@mix.wvu.edu 


\section{Appendix E}

Table E1

Symbols for Weighted Performance of Factors and Corresponding Indicators

\begin{tabular}{|c|c|}
\hline Variable & Meaning \\
\hline WP_SFF_WV & West Virginia's weighted performance on supporting factors and facilities \\
\hline WP_SFF_US & Other States weighted performance on supporting factors and facilities \\
\hline WP_Value_WV & West Virginia's weighted performance on value for money in shopping items \\
\hline WP_Value_US & Other states' weighted performance on value for money in shopping items \\
\hline WP_Res_WV & West Virginia's weighted performance on variety and quality on restaurants \\
\hline WP_Res_US & Other states' weighted performance on variety and quality on restaurants \\
\hline WP_AccA_WV & West Virginia's weighted performance on variety and quality on accommodation \\
\hline WP_AccA_US & Other states' weighted performance on variety and quality on accommodation \\
\hline WP_Trans_WV & West Virginia's weighted performance on local transportation efficiency \\
\hline WP_Trans_US & Other states' weighted performance on local transportation efficiency \\
\hline WP_Comm_WV & West Virginia's weighted performance on communication facilities \\
\hline WP_Comm_US & Other states' weighted performance on communication facilities \\
\hline WP_Road_WV & West Virginia's weighted performance on road conditions \\
\hline WP_Road_US & Other states' weighted performance on road conditions \\
\hline WP_Shop_WV & West Virginia's weighted performance on hopping facilities \\
\hline WP_Shop_US & Other states' weighted performance on hopping facilities \\
\hline WP_CR_WV & West Virginia's weighted performance on core resources \\
\hline WP_CR_US & Other states' weighted performance on core resources \\
\hline WP_Nat_WV & West Virginia's weighted performance on nature-based activities \\
\hline WP_Nat_US & Other states' weighted performance on nature-based activities \\
\hline WP_Tour_WV & West Virginia's weighted performance on value for money in tourism experiences \\
\hline WP_Tour_US & Other states' weighted performance on value for money in tourism experiences \\
\hline WP_Adv_WV & West Virginia's weighted performance on availability on adventure-based activities \\
\hline WP_Adv_US & Other states' weighted performance on availability on adventure-based activities \\
\hline WP_Wea_WV & West Virginia's weighted performance on good weather/climate \\
\hline
\end{tabular}


Table E1 (Continued)

Symbols for Weighted Performance of Factors and Corresponding Indicators

\begin{tabular}{|c|c|}
\hline Variable & Meaning \\
\hline WP_Wea_US & Other states' weighted performance on good weather/climate \\
\hline WP_AA_WV & West Virginia's attractions and accessibility \\
\hline WP_AA_US & Other states' attractions and accessibility \\
\hline WP_Land_WV & West Virginia's weighted performance on well-known landmarks \\
\hline WP_Land_US & Other states' weighted performance on well-known landmarks \\
\hline WP_Ded_WV & West Virginia's weighted performance on dedicated tourism attractions \\
\hline WP_Ded_US & Other states' weighted performance on dedicated tourism attractions \\
\hline WP_Spec_WV & West Virginia's weighted performance on special events \\
\hline WP_Spec_US & Other states' weighted performance on special events \\
\hline WP_Arc_WV & West Virginia's weighted performance on interesting architecture \\
\hline WP_Arc_US & Other states' weighted performance on interesting architecture \\
\hline WP_His_WV & West Virginia's weighted performance on historic sites \\
\hline WP_His_US & Other states' weighted performance on historic sites \\
\hline WP_Child_WV & West Virginia's weighted performance on availability on activities for children \\
\hline WP_Child_US & Other states' weighted performance on availability on activities for children \\
\hline WP_Con_WV & West Virginia's weighted performance on conveniently located \\
\hline WP_Con_US & Other states' weighted performance on conveniently located \\
\hline WP_Avail_WV & West Virginia's weighted performance on availability on tourist information \\
\hline WP_Avail_US & Other states' weighted performance on availability on tourist information \\
\hline WP_Act_WV & West Virginia's weighted performance on variety on activities to do \\
\hline WP_Act_US & Other states' weighted performance on variety on activities to do \\
\hline WP_QAD_WV & West Virginia's weighted performance on qualifying and amplifying determinants \\
\hline WP_QAD_WV & Other states' weighted performance on qualifying and amplifying determinants \\
\hline WP_Hosp_WV & West Virginia's weighted performance on hospitality \& friendliness on residents \\
\hline WP_Hosp_US & Other states' weighted performance on hospitality \& friendliness on residents \\
\hline WP_Saf_WV & West Virginia's weighted performance on safety and security \\
\hline
\end{tabular}


Table E1 (Continued)

Symbols for Weighted Performance of Factors and Corresponding Indicators
Variable
Meaning

WP_Saf_US Other states' weighted performance on safety and security

WP_Clean_WV West Virginia's weighted performance on cleanliness

WP_Clean_US Other states' weighted performance on cleanliness

WP_Mark_WV West Virginia's weighted performance on well-marked roads/attractions

WP_Mark_US Other states' weighted performance on well-marked roads/attractions

WP_Acc_WV West Virginia's weighted performance on accessibility on destination

WP_Acc_US Other states' weighted performance on accessibility on destination 
Table E2

Symbols for Non-weighted Performance of Factors

\begin{tabular}{ll}
\hline Variables & \\
\hline UP_SFF_WV & West Virginia's non-weighted performance on supporting factors and facilitates \\
UP_SFF_US & Other states' non-weighted performance on supporting factors and facilitates \\
UP_CR_WV & West Virginia's non-weighted performance on core resources \\
UP_CR_US & Other states' non-weighted performance on core resources \\
UP_AA_WV & West Virginia's non-weighted performance on attractions and accessibility \\
UP_AA_US & Other states' non-weighted performance on attractions and accessibility \\
UP_QAD_WV & West Virginia's non-weighted performance on qualifying and amplifying determinants \\
UP_QAD_US & Other states' non-weighted performance on qualifying and amplifying determinants \\
UP_O_WV & West Virginia's overall non-weighted performance on a destination \\
UP_O_US & Other states' overall non-weighted performance on a destination
\end{tabular}

